Article

\title{
Using Microcystin Gene Copies to Determine Potentially-Toxic Blooms, Example from a Shallow Eutrophic Lake Peipsi
}

\author{
Kristel Panksep 1,*(D), Marju Tamm ${ }^{1}$, Evanthia Mantzouki ${ }^{2}$, Anne Rantala-Ylinen ${ }^{3}$, \\ Reet Laugaste ${ }^{1}$, Kaarina Sivonen ${ }^{4}$, Olga Tammeorg ${ }^{1,5}$ and Veljo Kisand ${ }^{1,6}$ \\ 1 Chair of Hydrobiology and Fishery, Institute of Agricultural and Environmental Sciences, Estonian \\ University of Life Sciences, 51006 Tartu, Estonia \\ 2 Department F.-A. Forel for Environmental and Aquatic Sciences, University of Geneva, \\ 1205 Geneva, Switzerland \\ 3 Institute of Biotechnology, University of Helsinki, 00790 Helsinki, Finland \\ 4 Department of Microbiology, University of Helsinki, 00014 Helsinki, Finland \\ 5 Ecosystems and Environmental Research Programme, University of Helsinki, 00014 Helsinki, Finland \\ 6 Institute of Technology, University of Tartu, 50411 Tartu, Estonia \\ * Correspondence: kristel.panksep@emu.ee; Tel.: +372-53-497-898
}

Received: 31 January 2020; Accepted: 24 March 2020; Published: 26 March 2020

\begin{abstract}
Global warming, paired with eutrophication processes, is shifting phytoplankton communities towards the dominance of bloom-forming and potentially toxic cyanobacteria. The ecosystems of shallow lakes are especially vulnerable to these changes. Traditional monitoring via microscopy is not able to quantify the dynamics of toxin-producing cyanobacteria on a proper spatio-temporal scale. Molecular tools are highly sensitive and can be useful as an early warning tool for lake managers. We quantified the potential microcystin (MC) producers in Lake Peipsi using microscopy and quantitative polymerase chain reaction (qPCR) and analysed the relationship between the abundance of the $m c y E$ genes, MC concentration, MC variants and toxin quota per $m c y E$ gene. We also linked environmental factors to the cyanobacteria community composition. In Lake Peipsi, we found rather moderate MC concentrations, but microcystins and microcystin-producing cyanobacteria were widespread across the lake. Nitrate $\left(\mathrm{NO}_{3}{ }^{-}\right)$was a main driver behind the cyanobacterial community at the beginning of the growing season, while in late summer it was primarily associated with the soluble reactive phosphorus (SRP) concentration. A positive relationship was found between the MC quota per $m c y E$ gene and water temperature. The most abundant variant-MC-RR—was associated with MC quota per mcyE gene, while other MC variants did not show any significant impact.
\end{abstract}

Keywords: cyanobacteria; qPCR; mcyE; microcystins; MC quota; Lake Peipsi

Key Contribution: This manuscript describes the relationship between cyanobacterial community composition, the abundance of the $m c y E$ genes, MC concentrations, MC quota per $m c y E$ gene and environmental variables in large and shallow north temperate lakes.

\section{Introduction}

Eutrophication of aquatic systems caused by anthropogenic nutrient enrichment is a critical environmental problem of the 21st century [1,2]. Extensive research has shown that increased nutrient-loading shifts phytoplankton communities towards the dominance of bloom-forming and potentially toxic cyanobacteria [3-5]. However, many symptoms of eutrophication are affected 
and escalated by global warming, it was predicted that the extent and frequency of the harmful cyanobacterial blooms will increase in a warmer climate [6-10]. Anthropogenic pressures render shallow lake ecosystems especially vulnerable to environmental change and the subsequent boosting of cyanobacterial occurrence [11,12].

Cyanobacterial blooms pose a substantial health risk to humans and animal species due to the cyanotoxins they produce. These secondary metabolites are mainly stored inside the cyanobacterial cell and are released into the water during cell lysis, potentially leading to high toxin concentrations [13]. Aquatic life such as fish, crustaceans, mussels, and molluscs may also become toxic as cyanotoxins accumulate, moving up the food web [13-16]. Consequently, the dominance of cyanobacteria might cause considerable economic loss to fisheries and water supply companies, and decrease the recreational value of the water body and the market value of lakefront estates $[10,17,18]$. Rapidly changing environmental conditions may favor cyanobacterial growth over other species, with subsequent consequences such as habitat loss (e.g., hypoxic zones), disruption in energy flow along the food web, and decrease in biodiversity and ecosystem services [19-21].

Generally, cyanobacterial occurrence and dominance are significantly associated with three environmental variables and their interactions, nutrients, light and temperature, as reviewed in [22]. A high temperature stimulates cyanobacterial growth, with many species reaching their maximum growth rate above $25{ }^{\circ} \mathrm{C}[11,23]$. As the nutrient dynamics in lakes is strongly affected by the external loading of phosphorus $(\mathrm{P})$ and nitrogen $(\mathrm{N})$ [24], the abundance and community composition of cyanobacteria are mainly linked to these two environmental factors [25]. Traditionally, high $\mathrm{P}$ concentration is considered as the main risk factor for cyanobacterial blooms [26]. In shallow lakes, the internal load is also considered as an important source of dissolved $\mathrm{P}$ that becomes directly available for phytoplankton growth $[27,28]$. Several studies have also demonstrated the significance of $\mathrm{N}$ on promoting cyanobacterial blooms. While there has been a debate about whether $\mathrm{P}$ or $\mathrm{N}$ control algal growth, the importance of the dual control of nutrients is widely recognized in water quality management [29-31]. Because the geographical distribution and both the magnitude and frequency of cyanobacterial blooms is increasing [32], it is urgent to accurately monitor potentially toxic cyanobacteria and improve our understanding of the environmental factors that promote bloom formation.

Conventional monitoring methods rely on inverted microscopy [33] and spectrophotometric measurements of chlorophyll-a (chl-a) to quantify phytoplankton, including cyanobacteria. Both of these methods are insufficient to detect toxin-producing cyanobacteria [34] because toxic and non-toxic strains within the same species are often morphologically identical and might co-exist within the same sample [13]. Traditionally, cyanobacterial biomass has been used as an indicator of potential toxin presence, disregarding the fact that toxin concentrations can rapidly increase even in a lower cyanobacterial biomass [34]. Measurements of chl-a and some other pigments provide a rapid estimation of total algal biomass (particularly, combined with remote sensing) [35], but, even if more group-specific photosynthetic pigments, such as zeaxanthin or phycocyanin, are used as a proxy for cyanobacterial biomass, the toxicity potential remains unknown.

To evaluate the risks to public health, data on potentially toxic cyanobacteria and cyanotoxins need to be provided as early as possible [11]. DNA based methods (e.g., polymerase chain reaction-PCR and quantitative PCR) comprise a valuable toolbox for both the detection and quantification of potentially toxic cyanobacteria [25,36-38]. However, the relationship between the cellular microcystin (MC) concentration and the copy number of mcy genes or MC producer's biomass is not straightforward. The amount of microcystin per unit of biomass (toxin quota per biomass) depends on various factors such as genotype, nutrient availability and temperature. The general understanding about the amount of toxin per cell under different environmental conditions is still poorly understood due to the availability of only a limited number of in situ studies. As the toxin quota per cell directly reflects the safety of the waterbody, it is important to clarify how the copy number of mcy genes, MC concentration and environmental factors are related to this specific parameter. Quantitative PCR (qPCR) is a time- and cost-effective tool to evaluate the proportion of potential toxin-producing genotypes over 
the cyanobacterial population, as well as to investigate how environmental parameters determine toxicity potential at the spatio-temporal scale $[25,34]$. Consequently, qPCR can help us understand the mechanisms that trigger toxic blooms and can be used as an early warning tool for lake managers.

Lake Peipsi is the largest transboundary lake in Europe, located on the border of Estonia and Russia (Figure 1). This large (area $3555 \mathrm{~km}^{2}$ ), shallow (mean depth $7.1 \mathrm{~m}$ ) and unstratified lowland water body consists of three basins (Figure 1, Table A1). The northernmost Lake Peipsi sensu stricto (s.s.) with a very simple shoreline is the deepest part of the lake. The southernmost basin is Lake Pihkva and these two lakes are connected by riverlike Lake Lämmijärv [39]. These three basins are all different in trophic state, hydrology and morphometry [40]. The bottom topography of Lake Lämmijärv is remarkably different to the other basins and also the water temperature in spring and winter tends to be warmer than in Peipsi s.s. and Lake Pihkva [39]. According to the OECD (1982) classification, Lake Peipsi s.s. is considered as eutrophic and Lämmijärv and Pihkva basins are considered as hypertrophic parts of the lake (Table 1, Figure 1). Rivers Velikaya and Emajõgi, the main inflows, carry the majority $(>80 \%)$ of nutrients into the lake [41,42]. The outflow from the lake, River Narva, discharges into the Gulf of Finland. Lake Peipsi has been strongly influenced by eutrophication and natural fluctuations in water level and temperature [40]. Due to these processes, massive cyanobacterial blooms have been common for several decades [43-45].

In this study, samples from Lake Peipsi and its basins (Figure 1; Table A1) were analysed for the presence and abundance of potentially toxic Microcystis, Dolichospermum and Planktothrix using qPCR. The concentration and variants of microcystins were analysed using liquid chromatography-mass spectrometry (LC-MS/MS). Microscopic analysis of the samples was conducted to analyse the cyanobacterial community composition. Although several studies on the occurrence of cyanobacteria in Lake Peipsi have been published [41,44,46-49], only one of these addresses the issue of toxicity and toxin concentrations [49]. In general, there are significantly less data and fewer studies on cyanotoxins from Eastern Europe, with Estonia being presented with only one publication [50]. The current study is the first to combine molecular tools with traditional methods to determine the potential for cyanobacterial toxicity in this large and shallow north temperate lake.

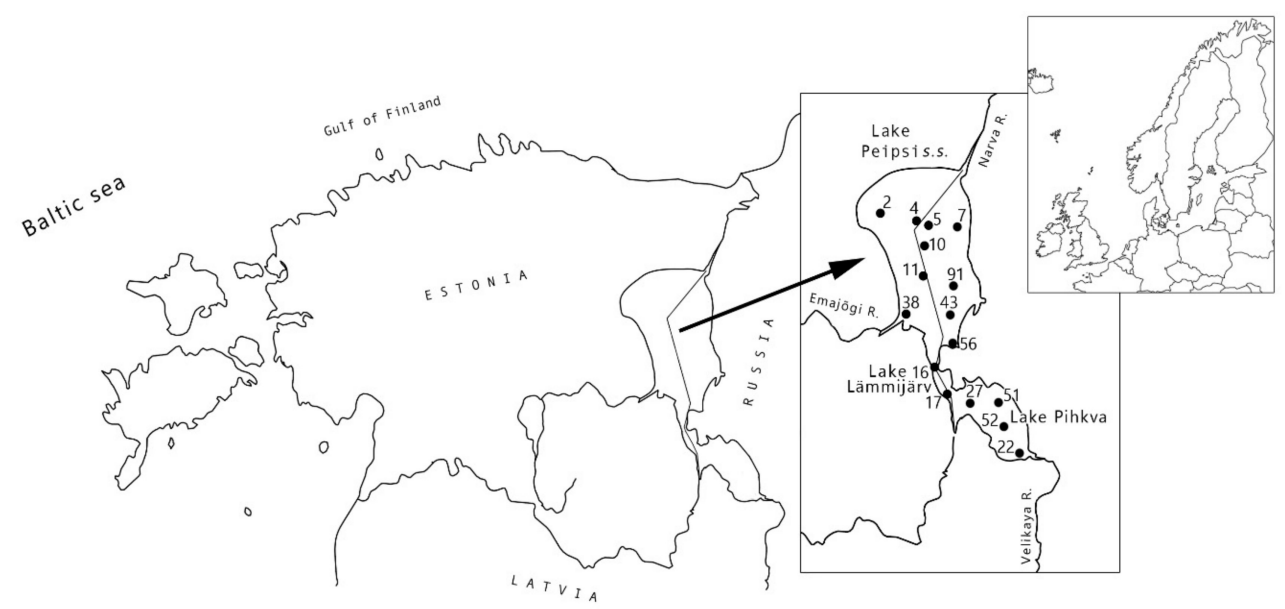

Figure 1. Location of Lake Peipsi (Estonia/Russia) and the sampling stations under study. Samples from Lake Pihkva (Russia) are collected in August only.

Here, we aim to (1) analyse cyanobacterial community composition in ecologically contrasting basins of Lake Peipsi and use molecular markers to identify and quantify the potential microcystin producers in the lake, (2) determine the relationship between toxin quota, the abundance of $m c y E$ genes and MC concentrations, and (3) elucidate the environmental factors that promote toxic cyanobacterial blooms. Our first hypothesis is that the number of $m c y E$ copies will follow an increase in toxin concentration. In our second hypothesis, we assume that in Lake Peipsi, mcyE gene copy number can 
be potentially used as a predictor of MC concentration. Additionally, we hypothesize that specific toxin variants are directly related to certain cyanobacterial genera.

\section{Results}

\subsection{Environmental Variables}

During the study period, the basins of Lake Peipsi were characterized by different water quality parameters and general characteristics (Table 1). Across the lake basins, spatial gradients occurred in the trophic state. Total phosphorus (TP), soluble reactive phosphorus (SRP), total nitrogen (TN) and chl-a values increased from the northern basin towards the southern basins.

Table 1. Water quality characteristics for three basins of Lake Peipsi (Lake Peipsi sensu stricto, Lake Lämmijärv, Lake Pihkva.

\begin{tabular}{|c|c|c|c|c|c|c|}
\hline \multirow{2}{*}{ Characteristic } & \multicolumn{2}{|c|}{ Peipsi s.s. * } & \multicolumn{2}{|c|}{ Lämmijärv * } & \multicolumn{2}{|c|}{ Pihkva ** } \\
\hline & Mean & Range & Mean & Range & Mean & Range \\
\hline Number of Samples & 91 & & 38 & & 12 & \\
\hline Area, $\mathrm{km}^{2}$ & 2611 & & 236 & & 708 & \\
\hline Mean depth, $\mathrm{m}$ & 8.3 & & 2.5 & & 3.8 & \\
\hline Max depth, m & 12.9 & & 15.3 & & 5.3 & \\
\hline Volume, $\mathrm{km}^{3}$ & 21.79 & & 0.6 & & 2.68 & \\
\hline $\mathrm{TP}, \mathrm{mg} / \mathrm{m}^{3}$ & 41 & $15-70$ & 75 & $36-110$ & 116 & $88-170$ \\
\hline $\mathrm{SRP}, \mathrm{mg} / \mathrm{m}^{3}$ & 12 & $2-49$ & 13 & $3-25$ & 28 & $13-79$ \\
\hline $\mathrm{TN}, \mathrm{mg} / \mathrm{m}^{3}$ & 701 & $460-1500$ & 1001 & 410-1500 & 1147 & $950-1400$ \\
\hline $\mathrm{NO}_{3}{ }^{-}, \mathrm{mg} / \mathrm{m}^{3}$ & 91 & 15-930 & 115 & $30-820$ & 91 & $30-220$ \\
\hline $\mathrm{NO}_{2}{ }^{-}, \mathrm{mg} / \mathrm{m}^{3}$ & 2 & 2-9 & 3 & $2-15$ & 3 & $2-5$ \\
\hline $\mathrm{NH}_{4}{ }^{+}, \mathrm{mg} / \mathrm{m}^{3}$ & 28 & $10-162$ & 25 & $10-120$ & 24 & $10-58$ \\
\hline chl-a, mg/m $\mathrm{m}^{3}$ & 23.3 & $6.9-52.4$ & 49.1 & $20.5-79$ & 61.2 & $41.4-78.3$ \\
\hline $\mathrm{pH}$ & 8.5 & $8-8.9$ & 8.6 & $8.3-9$ & 8.9 & $8.4-9.2$ \\
\hline Water temp, ${ }^{\circ} \mathrm{C}$ & 18.2 & $5-23.9$ & 17.9 & $10.3-24.7$ & 22 & $19.7-25.6$ \\
\hline Secchi depth, $\mathrm{m}$ & 1.64 & $0.9-3.5$ & 0.87 & $0.6-1.3$ & 0.67 & $0.4-0.9$ \\
\hline OECD classification & \multicolumn{2}{|c|}{ Eutrophic } & \multicolumn{2}{|c|}{ Eutrophic/hypertrophic } & \multicolumn{2}{|c|}{ Hypertrophic } \\
\hline
\end{tabular}

\subsection{The Composition of the Cyanobacterial Community Based on Microscopy}

During the growing season (May-October) across the basins of Lake Peipsi, cyanobacteria and diatoms prevailed in the phytoplankton biomass, while chlorophytes and cryptomonads prevailed in abundance. During the period of 2010-2012, cyanobacterial biomass varied from 0-16.03 mg wet weight/L (mgWW/L) and dominated in the summer months (July-August) or early autumn (September). The main potentially toxic cyanobacteria in the lake were from $\mathrm{N}_{2}$-fixing heterocystous genera Gloeotrichia, Dolichospermum, Aphanizomenon, and non-heterocystous Microcystis and Planktothrix. The biomass of the genus Microcystis exceeded other genera manifolds (median $1.7 \mathrm{mgWW} / \mathrm{L}$, maximum $14.5 \mathrm{mgWW} / \mathrm{L}$ in August), and was dominant among potentially toxic algae. Planktothrix attained a peak in September (maximum $2.2 \mathrm{mgWW} / \mathrm{L}$ ) and Dolichospermum at the beginning of July, with maximum biomass of $2.4 \mathrm{mgWW} / \mathrm{L}$ (Figure 2). Gloeotrichia occurred sporadically in some regions of Peipsi sensu stricto (s.s.) and only a few times in Lämmijärv. Aphanizomenon was omnipresent in the lake, being more numerous in Peipsi s.s. Other potentially toxic genera appeared all over the lake with larger biomasses in southern basins, and lakes Lämmijärv and Pihkva [43]. Multivariate comparison between-groups principal component analysis (bgPCA) revealed a clear spatial distribution of cyanobacterial community composition in different basins of Lake Peipsi (permutation test, $p<0.01$ ) (Figure 3). The cyanobacterial community composition in Peipsi s.s. varied considerably (permutation test, $p<0.01$ ) from the communities in Lämmijärv and Pihkva. Additionally, the effect of the inflow from Emajõgi River was evident in station 38 , which was significantly different (permutation test, $p<0.01$ ) from the other areas (Figure 3). 


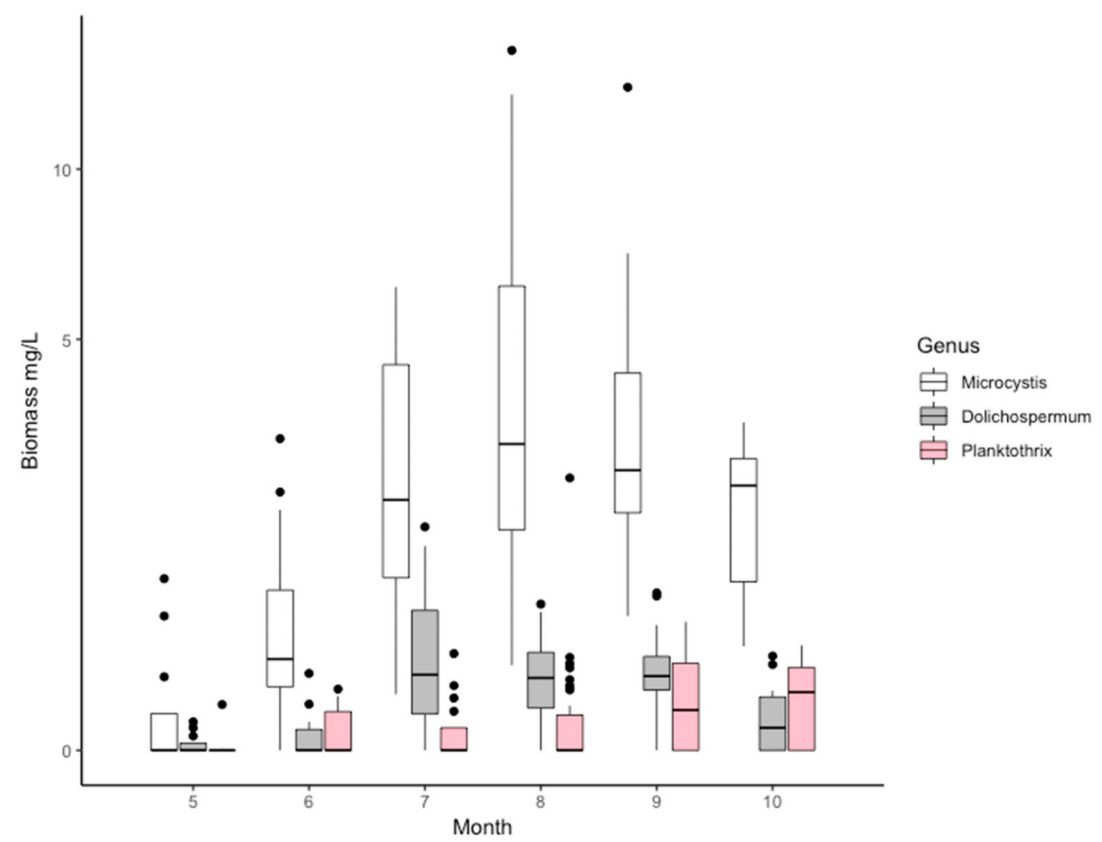

Figure 2. Temporal variation in Microcystis, Dolichospermum and Planktothrix biomass (mgWW/L). Boxplots denote median biomass values across the basins of Lake Peipsi and error bars represent spatial variation across the sampling stations. The y-axis is plotted as square root scale, values of biomass remain as original.

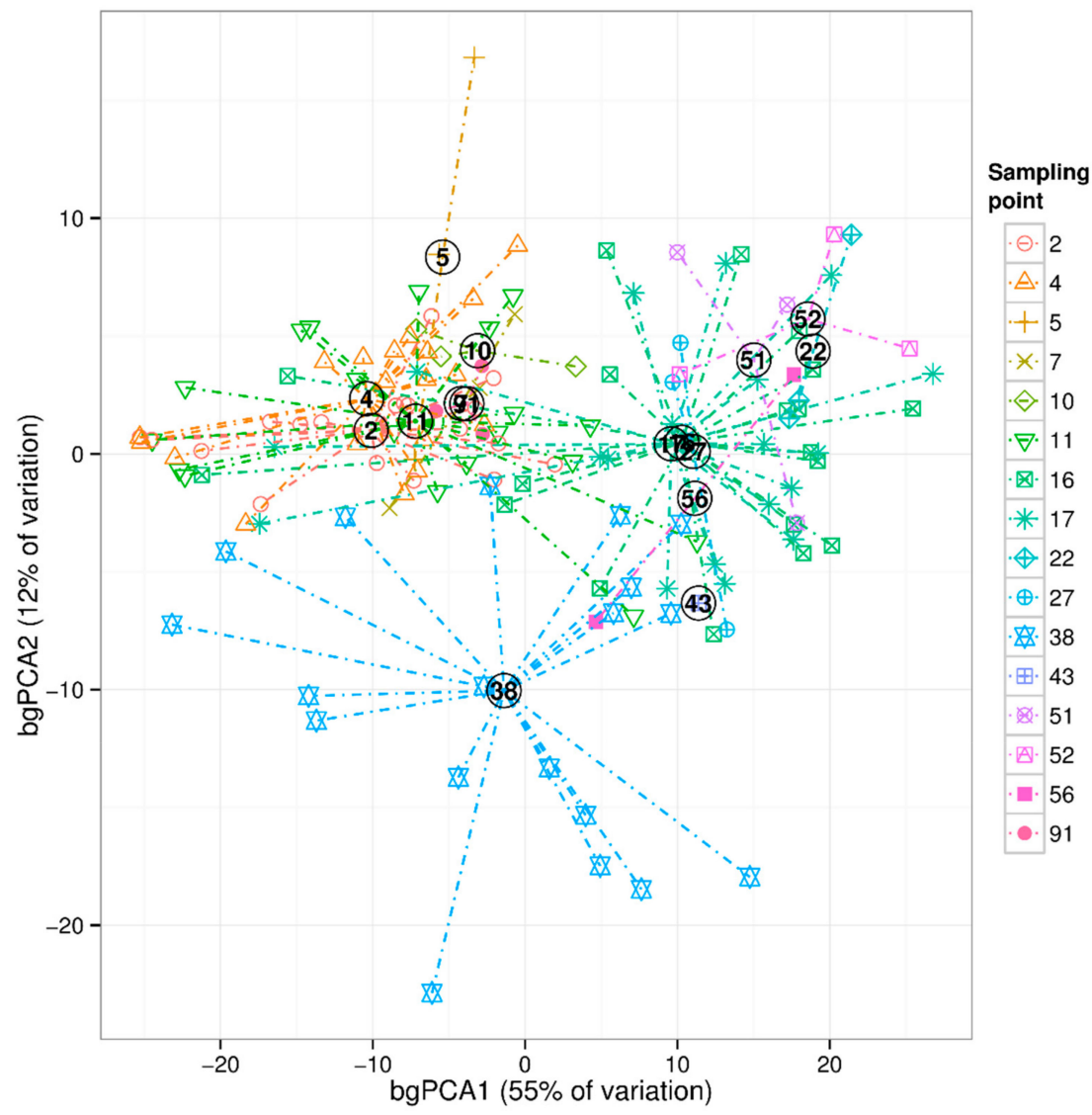

Figure 3. Cyanobacterial community composition in different basins (sampling stations) of Lake Peipsi. Sampling points 2, 4, 5, 7, 10, 11, 38, 43, 56 and 91 are located in Lake Peipsi s.s.; sampling points 16 and 17 in Lake Lämmijärv, and 22, 27, 51, 52 in Lake Pihkva. 


\subsection{Abundance of moyE Genes}

A simultaneous occurrence of the main MC producers was observed in all regions of the lake. In $80 \%$ of the samples, all three genera appeared concurrently. Microcystis $m c y E$ genes were found in all of the samples $(N=141)$, Dolichospermum mcyE and Planktothrix mcyE were found in $95 \%$ and $83 \%$ of the samples, respectively. Compared to the other genera, Microcystis mcyE copy numbers were most abundant (Wilcoxon pairwise test, $p<0.01$ ) over the entire growing season (median $1.89 \times 10^{5}$ gene copy/mL, minimum 0 and maximum $2.6 \times 10^{7}$ gene copy/mL, Figure 4 ). Dolichospermum mcyE and Planktothrix mcyE copy numbers were more comparable (median values $4.6 \times 10^{1}$ and $2.3 \times 10^{2}$ gene copy/mL; minimum 0 and 0 , maximum values $4.05 \times 10^{4}$ and $7.46 \times 10^{4}$ gene copy/mL, respectively). Positive correlations were found between the biomass and the toxin-producing gene abundances for Microcystis $(r=0.6 ; p<0.01)$, Dolichospermum $(r=0.31 ; p<0.01)$ and Planktothrix $(r=0.62 ; p<0.01)$.

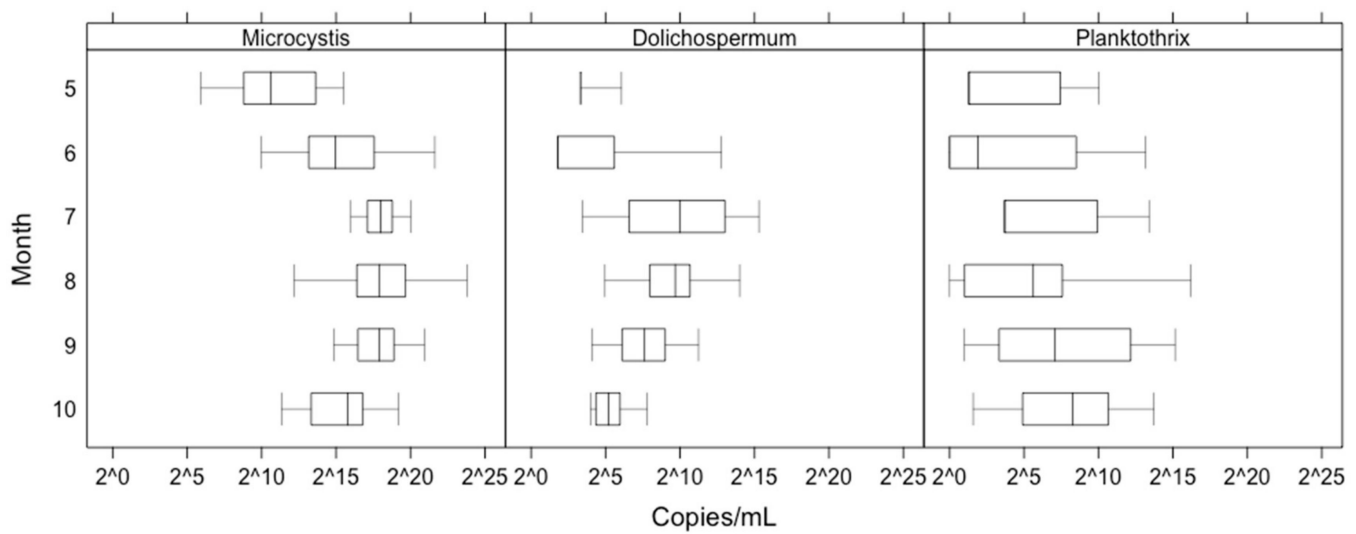

Figure 4. Temporal variation in Microcystis, Dolichospermum and Planktothrix mcyE gene copy number ( $m c y E$ gene/mL). Boxplots denote median $m c y E$ copy numbers across the basins of Lake Peipsi. Error bars represent spatial variation across the sampling stations. On all three panels, the y-axis is plotted $\log _{2}$ scale and the values of McyE copies remain original.

The seasonal pattern of the values of toxic genotypes was consistent with the dynamics of the total MC concentrations (Figure $5 \mathrm{a}, \mathrm{b}$ ). The total microcystin concentration had a statistically significant positive correlation $\left(\mathrm{r}_{\mathrm{p}}=0.67 ; p<0.01 ; n=69\right)$ with the sum of Microcystis, Dolichospermum and Planktothrix mcyE gene copy numbers (Figure S1). The seasonal dynamics of the microcystin quota (particulate microcystin per unit of $m c y E$ gene) was different from the seasonal dynamics of the MC concentration: a lower microcystin quota per $m c y E$ gene occurred together with higher MC concentrations (Figure 5c) and vice versa. There was a strong negative correlation between MC quota per $m c y E$ gene and $m c y E$ gene copy number $(r=-0.75 ; p<0.01 ; n=69)$. Logistic regression analysis demonstrated a correlation between MC-RR presence/absence and microcystin quota per $m c y E$ gene $(z=2.36 ; p<0.05)$; however, there was no statistically significant correlation between other MC variants and $\mathrm{MC}$ quota per $m c y E$ gene. $\mathrm{MC}$ quota per $m c y E$ gene was positively related to water temperature and $\mathrm{pH}\left(\mathrm{r}_{\mathrm{s}}=0.46\right.$ and 0.31 respectively, $\left.p<0.05 ; n=69\right)$ negatively related to nitrate concentration $\left(r_{\mathrm{s}}=-0.30\right)$, yet no significant correlation was found between MC quota per mcyE gene and both TP and TN. The correlation with the toxin quota calculated per unit of chlorophyll-a resulted in similar relationships to these environmental parameters $\left(r_{s}=0.47\right.$ and 0.50 , respectively, for temperature and $\mathrm{pH}$, and $\mathrm{r}_{\mathrm{s}}=-0.38$ for nitrate; $\left.p<0.05 ; n=69\right)$.

According to the literature data [25,32], 36 species of cyanobacteria in Lake Peipsi are potentially toxic. A Mantel permutation test showed a significant relationship between the biomass of potentially toxic species and $m c y E$ gene abundances $(r=0.43, p<0.01,999$ permutations, $n=141)$. At the same time, there was no statistically significant correlation between the biomass of other non-toxin producing cyanobacteria and mcyE abundance ( $r<0.01, p=0.53$, permutations $n=999, n=141)$. 

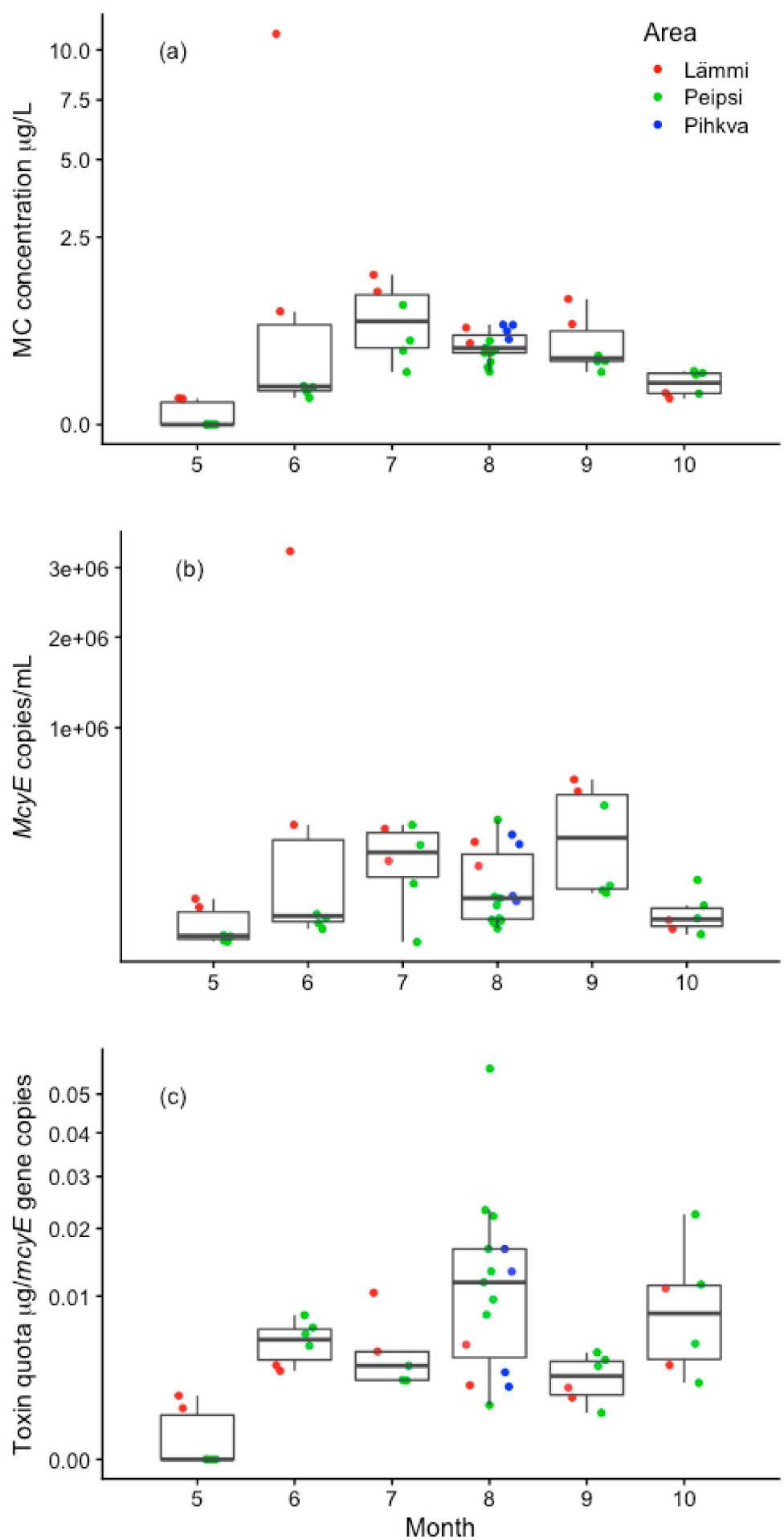

Figure 5. Temporal variation in total cell-bound microcystin (MC) concentration (a), the abundance of total $m c y E$ genes (b) and toxin quota per $m c y E$ gene-cell-bound MC per unit of $m c y E$ gene (c) in the year 2012. Boxplots denote the median values of all basins and error bars represent spatial variation across all sampling stations. Points represent measurements in a specific lake basin. The y-axis is plotted as square root scale (MC concentration, $M c y E$ copies and Toxin quota per mcyE gene values remain original). 


\subsection{Microcystin- Concentrations and Variants}

In this study, MCs were found in all samples analysed $(n=69)$. With a few exceptions, the microcystin concentration in the samples was relatively low, ranging from 0.001-10.9 $\mu \mathrm{g} / \mathrm{L}$, median $0.4 \mu \mathrm{g} / \mathrm{L}$. The maximum concentration was measured in mid-July 2012 in Lämmijärv, when Microcystis wesenbergii (Komárek) Komárek ex Komárek dominated. Based on LC-MS/MS, a total of 14 MC variants were found and eight of them were identified (MC-RR; [D-Asp3]MC-RR; [Dha7]MC-RR; MC-LR; [D-Asp3]MC-LR; [Dha7]MC-LR; MC-YR; [Dha7]MC-YR). Microcystin-RR was the most abundant MC variant, found in $93 \%$ of samples, followed by MC-LR and its methylated variants in $92 \%$ of the samples. In $60 \%$ of the samples, all identified MCs co-existed. Both PCA analysis and linear fitting of environmental variables (Figure 6) demonstrate a clear pattern of the distribution of MC variants, gene copy numbers, and the biomass of potentially MC-producing species. During the entire growing season, all variants of $\mathrm{MC}$ were detected in samples from Lämmijärv, while all MC variants were detected in samples from Peipsi s.s. only during the late growing season. [D-Asp3]MC-RR was correlated with Planktothrix agardhii Gomont, Anagnostidis and Komarek in the southern basins (Lämmijärv and Pihkva) from July until the end of the sampling period. Other MC variants formed a close group with M. wesenbergii, Microcystis aeruginosa (Kützing) Kützing and Dolichospermum flos-aquae (Brébisson ex Bornet and Flahault) P. Wacklin et al. Concurrently, Dolichospermum circinale (Rabenh.) Wacklin et al., and M. wesenbergii were also highly related to mcyE gene copy numbers.

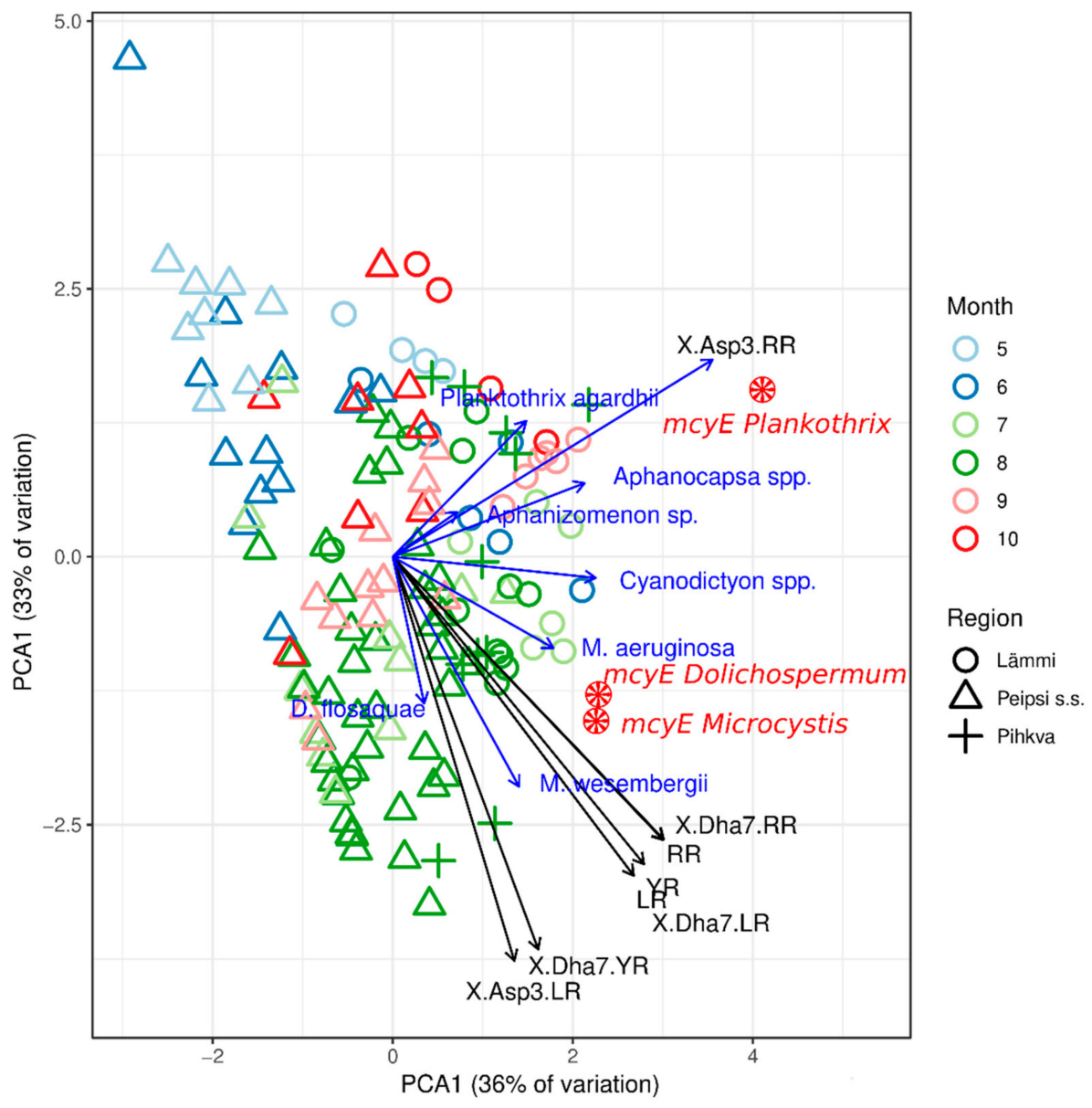

Figure 6. Multivariate comparisons of various $m c y E$ gene abundances, cyanobacterial community and the presence/absence of MC variants. Significance $(p<0.05)$ of these linear fittings was obtained by a permutation test (1000 replicates). The length and direction of vectors indicate the strength and direction of the relationship. 


\subsection{Environmental Variables that Favour Potentially Toxic Cyanobacteria Genotypes}

A principal component analysis was performed using the cyanobacterial community composition as variables and linearly fitting the environmental variables, such as basic nutrients (TP, SRP, TN, $\mathrm{NO}_{3}-$, $\mathrm{NO}_{2-}, \mathrm{NH}_{4}+$ ) and temperature with a PCA ordination space. The analyses revealed a significant but mostly weak association with the distributions of environmental variables that favor cyanobacteria in Lämmijärv and Peipsi s.s. (Figure 7$)$. In the early growing season, water temperature $\left(\mathrm{r}^{2}=0.14 ; p<0.05\right)$ and nitrate $\left(\mathrm{r}^{2}=0.19 ; p<0.01\right)$ were the main factors associated with cyanobacterial abundance in both lake basins. From August to October, in Peipsi s.s., soluble reactive phosphorus (SRP) $\left(\mathrm{r}^{2}=0.14\right.$; $p<0.05)$, and in Lämmijärv total nitrogen $\left(\mathrm{r}^{2}=0.28 ; p<0.001\right)$ and total phosphorus $\left(\mathrm{r}^{2}=0.69\right.$; $p<0.01$ ) were the most important environmental descriptors related to the cyanobacterial community composition. Other environmental parameters (e.g., $\mathrm{NH}_{4}{ }^{+}, \mathrm{NO}_{2}{ }^{-}$etc.) were analysed as well, but no significant correlations were found with the cyanobacterial community.

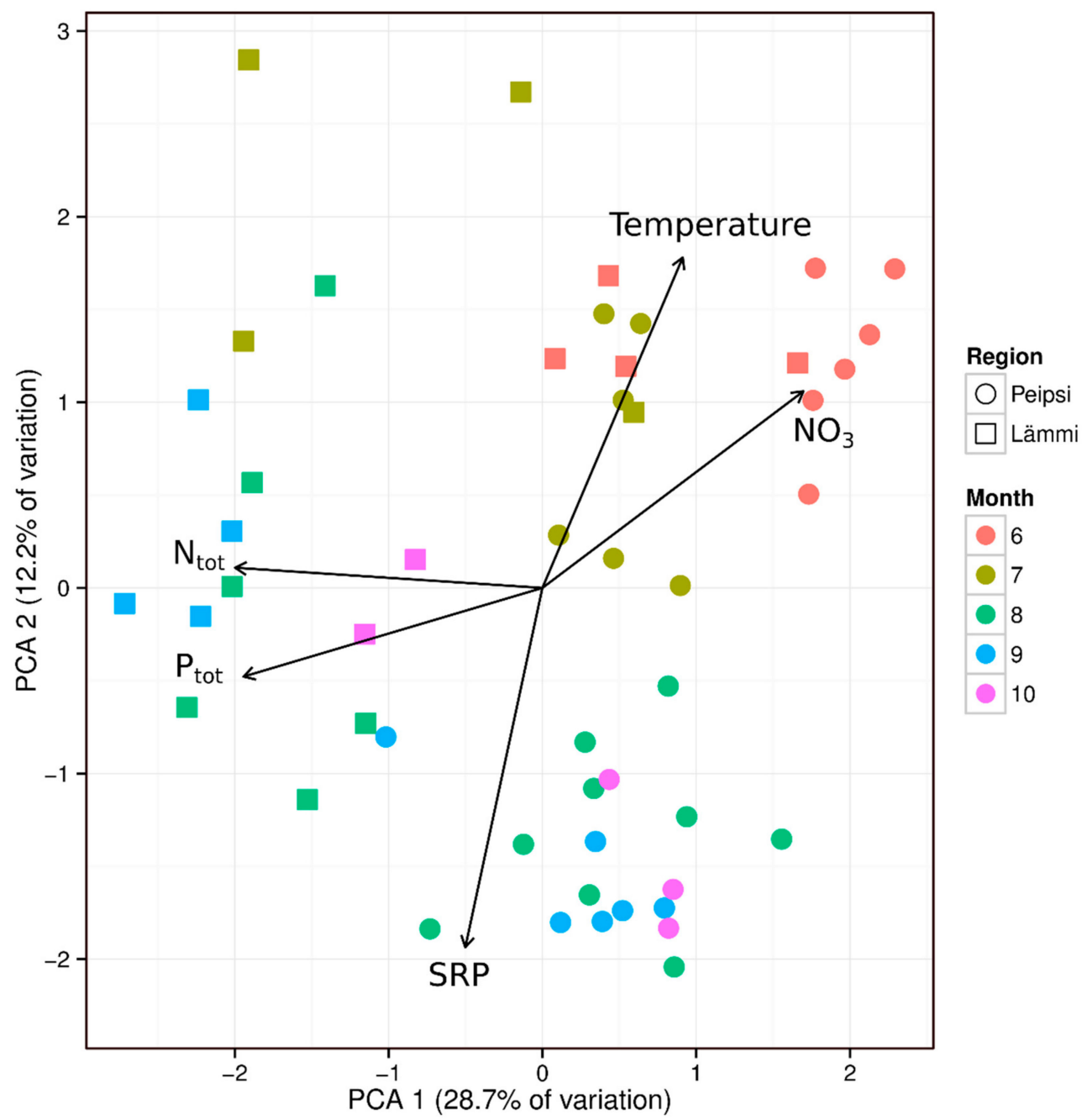

Figure 7. Multivariate comparisons of the abundance of cyanobacteria and environmental physico-chemical variables. Significance $(p<0.05)$ of these linear fittings was obtained by permutation test (1000 replicates). The length and direction of vectors indicate the strength and direction of the relationship.

\section{Discussion}

Cyanobacterial occurrence and dominance are mainly associated with eutrophication processes [4]. One of the initial aims of this study was to identify differences in the cyanobacterial community composition along a trophic gradient and to determine which cyanobacteria genus is the main potential 
microcystin producer in the shallow eutrophic-hypertrophic Lake Peipsi. The current study revealed a clear spatial distribution of cyanobacterial community composition in ecologically contrasting basins of this large and shallow lake. The cyanobacterial community composition in the eutrophic part of the lake varied considerably from the communities in hypertrophic basins (Figure 3, Table 1, Table A1). This observation is in accordance with a previous study that demonstrated remarkable differences between Peipsi s.s., Lämmijärv and Pihkva [44]. The most abundant species were Microcystis viridis (A. Braun) Lemm., M. wesenbergii, Dolichospermum. circinale, D. crassum (Lemm.) Wacklin et al., D. lemmermannii (Richter) Wacklin et al., Planktothrix agardhii, Aphanizomenon flos-aquae Ralfs and Gloeotrichia echinulata (J.S. Smith, P. Richter). A more detailed overview of species composition is provided in Table S1. Those findings are in agreement with data from systematic monitoring of Lake Peipsi, which has been carried out for six decades. According to the existing data [43], cyanobacterial blooms in the northern part of Peipsi s.s. are mainly attributed to G. echinulata. At the same time, several potential microcystin producers from genus Microcystis, Dolichospermum and Planktothrix occur in the southern part of Peipsi s.s. and Lämmijärv. A. flos-aquae has occurred in the lake in all years studied until the late autumn [43-46].

Another aim of this study was to use molecular markers to identify and quantify the potential microcystin producers in the basins of Lake Peipsi. For that purpose, genus-specific qPCR was used. Because microcystins are considered a major threat to human and animal health worldwide [51], we primarily focused on the genetic markers of the three most common microcystin-producing genera in Lake Peipsi (Microcystis, Dolichospermum and Planktothrix). Molecular analysis of potential MC producers revealed a simultaneous occurrence in all regions of the lake and $80 \%$ of the samples, with all three genera appearing concurrently (Figure 4). During the productive season (May to Oct), Microcystis mcyE copy numbers were the most abundant, while the abundance of Dolichospermum $m c y E$ and Planktothrix mcyE copies were considerably lower. This result is not surprising because species from Microcystis are highly adaptive for various environments [52], and thus are the most commonly found microcystin producers in all eutrophic waters worldwide [13,51]. Although it is clear that the genus Microcystis was the dominant potential MC producer in Lake Peipsi, other genera also had their maximum peak periods (Figure 4). The ecological preferences of the different genera might provide an explanation. Dolichospermum had its peak in July, when the average water temperature was higher (mean $21.2^{\circ} \mathrm{C}$ ) and the water column more prone for stratification. Stratification periods give a competitive advantage for cyanobacterial species with gas-vacuoles (e.g., Dolichospermum and Aphanizomenon), as, due to their ability to regulate their position in the water column, they can optimise their use of nutrients and light [7]. However, it should be noted that with the given data it is difficult to assess the relative importance of direct temperature effects compared to the indirect effects or general climatic differences between seasons. In August, Microcystis dominated, and in September Planktothrix reached their peak. While water temperature in August was comparable with the temperature in July (mean $20.6{ }^{\circ} \mathrm{C}$ ), in September the average temperature was only $14.4^{\circ} \mathrm{C}$. Compared to other genera, Planktothrix thrives in cooler water temperatures and is well adapted to lower temperatures [53]. This can explain its biomass peak in Lake Peipsi during the autumn months. Due to its low-light tolerance [54], P. agardhii can proliferate throughout a well-mixed shallow water column in the southern basins of the lake (Table A1), where the Secchi depth is significantly lower.

In late summer, the abundance of cyanobacteria was primarily associated with the concentration of SRP (Figure 7) in Lake Peipsi s.s., suggesting that the dominance of cyanobacteria and biomass of the major microcystin producer is mainly controlled by P dynamics. Similarly, the recent studies in Lake Peipsi and other shallow eutrophic lakes of the north temperate region have shown that internal $\mathrm{P}$ loading provides considerable amounts of bioavailable $\mathrm{P}$ to the water column, which contributes to the growth of cyanobacteria in summer [48,55-59]. Under turbid conditions and warm water temperatures, cyanobacteria gain an advantage over eukaryotic phytoplankton groups, as they can control their buoyancy to maximise the light use, maintain growth rates in warmer temperatures, fix atmospheric nitrogen, and therefore take advantage of the use that is provided by internal loading during $\mathrm{N}$-limited 
periods $[28,60]$. Furthermore, several species of cyanobacteria are able to uptake and store bioavailable phosphorus, and thus the populations can sustain themselves on internal P storage [52]. Changes in the factors that regulate cyanobacteria abundance between early and late times of the growing season reported in the current study are most likely related to the changes in the relative importance of the sources of nutrient supply, as they are closely coupled to the seasonality of nutrient dynamics in Lake Peipsi [61,62]. Moreover, different cyanobacteria species may assimilate nutrients at different rates. This is supported by another of our findings: the clear spatial distribution of cyanobacterial community composition (Figure 3) in the basins of Lake Peipsi that we studied are characterized by the different trophy. The finding that $\mathrm{NO}_{3}{ }^{-}$(Figure 7) was the main driver shaping the cyanobacterial community composition at the beginning of the growing season in all basins of Lake Peipsi, and TN, together with $\mathrm{TP}$, are influential factors during the late growing season in Lake Lämmijärv, may imply that $\mathrm{N}$ also has to be considered in lake water quality management aimed at reducing cyanobacteria.

\subsection{Concentration Versus MC Variants}

During the study period, MC concentrations measured from lake water samples were in a range (median $0.4 \mu \mathrm{g} / \mathrm{L}$ ) comparable to other various large lakes such as Taihu [63,64], Chaohu [65], Green Bay of Lake Michigan [66] and Erie [67,68]. In a study where 143 lakes in New Zealand were investigated, the authors also reported rather low MC concentrations $(<1 \mu \mathrm{g} / \mathrm{L})$ in the majority of lakes [69]. Comparable MC concentrations were also found in another large and shallow Estonian lake, Võrtsjärv [70]. Our toxin concentrations, measured in Lake Peipsi, were comparable with MC concentrations from the year 2003, reported in a study by Tanner et al. [49]. Tanner and others [49] demonstrated that even when the MC concentration in the open water column is relatively low, the MC concentration was extremely high in the inshore areas where biomass may accumulate and most human and animal activity occurs (33 to 54 times higher compared to the open water). Inshore samples were not analysed during the current study because MC concentrations were not measured, however, $m c y E$ copy numbers in inshore waters were extremely high, reaching 57 million gene copies per $\mathrm{mL}$ [70]. Species from Microcystis and Dolichospermum are able to form surface scums and, under favourable environmental conditions (e.g., abundant sunlight, warm temperature and still water-column), the density of potentially toxic cells can rapidly increase within a few hours [1]. If the wind sweeps these scums to the shore, it can present a very high risk for the people using the waterbody recreationally. In 2002, the MC concentration measured in the shoreline scum of Lake Peipsi was $2183 \mu \mathrm{g} / \mathrm{L}$, even when the MC concentration in the open water was rather low [49]. Therefore, we can conclude that even moderate concentrations of microcystins in the open water area of the lake can pose a high risk for bathers if, under the right conditions, surface scums form and concentrate in shoreline areas.

In Lake Peipsi, a total of $14 \mathrm{MC}$ variants were found and eight of them were identified. The most abundant MC variants were MC-RR, found in $93 \%$ of the samples, and MC-LR with its variants, found in $92 \%$ of the samples. MC-RR, together with MC-LR and MC-YR and their variants are the most commonly reported microcystins [51,71] and MC-LR is quite often mentioned as the most frequent MC.

More variants and a higher concentration of microcystins are often found in more eutrophic waters [66]. This is in accordance with our findings, showing that all analysed variants of MCs were detected in more eutrophic Lake Lämmijärv during the entire growing season, while in Lake Peipsi s.s. they were detected only during the late growing season. In the hypertrophic part of Lake Peipsi, P. agardhii was only significantly related with [D-Asp3]MC-RR (Figure 6) and the abundance of Planktothrix mcyE genes showed a significant correlation to this MC variant. This finding is in accordance with the study [72], where Sivonen and others found that Planktothrix isolates from Finnish lakes were able to produce only one of two types of microcystins ([D-Asp3]MC-RR or [Dha7]MC-RR), and not other MC variants. In Lake Peipsi, other MC variants formed a group with $M$. wesenbergii, $M$. aeruginosa in the southern parts of the lake and D. flos-aquae in Peipsi s.s. Thus, our third hypothesis that specific toxin variants are directly related to certain cyanobacterial genera was mainly supported. In Lake Peipsi, the presence of MC-RR was associated with MC quota per mcyE gene, while other 
MC variants did not show any significant impact. One possible explanation for this might be that microcystin-RR was also the most abundant MC variant found in the samples.

The microcystin concentration displayed a statistically significant positive correlation with the sum of Microcystis, Dolichospermum and Planktothrix mcyE gene copy numbers (Figure S1). These results are in accordance with our first hypothesis. This demonstrates that $m c y E$ gene abundance could be used to estimate toxin production. A review from Pacheco and others [34] regarding the use of qPCR to assess the toxicity of cyanobacterial blooms showed that 22 studies out of 33 (years 2003-2015) reported a persistent positive correlation between mcy gene copies and MC concentrations. In $80 \%$ of the studies that adopted $m c y E$ gene detection, positive correlations were found [34]. Additionally, under the framework of the European Multi Lake Survey (EMLS) [73,74], where lakes across Europe were sampled once in a snapshot approach in 2015, a strong significant correlation between the abundance of $m c y E$ gene and MC concentrations was found in 200 lakes [75]. In the current study, the advantage of $m c y E$ gene abundance for the prediction of MC production was also confirmed by the analysis of the relationship between microscopy counts of cyanobacterial species that are known to produce toxins, $\mathrm{MC}$ concentrations and $m c y E$ gene abundance. Still, it should be considered that, even though the correlation of the MC concentration and $m c y E$ gene abundance is very strong, the number of gene copies merely reveals the potential to produce the toxin, and does not indicate if the genes of interest are actively expressed and toxins are produced $[63,76]$. Despite the positive detection of potentially toxic genotypes of cyanobacteria, mutations can inactivate the genes involved in the biosynthesis of toxins, and thus hinder toxin production $[77,78]$. Therefore, to confirm the presence and estimate the concentration of cyanotoxins in the water, chemical analytical methods, such as LC-MS/MS or HPLC, are still required [79]. In order to elucidate the processes underlying toxin dynamics in more detail in this freshwater system, further exploration focusing on measuring the expression of toxin genes along with toxin concentration and other lake parameters would be necessary.

\subsection{Toxin Quota per McyE Gene}

The concentration of toxins in the water is related to the abundance of toxin-producing species and the amount of toxin per cell. [80]. Generally, the toxin quota is described as the amount per unit of either biomass or chl-a $[73,80]$. In the current study, the microcystin quota was calculated as the microcystin concentration per unit of $m y c E$ gene, and we used this to elucidate the direct relationship between the abundance of toxin genes and MC concentration. Even though a significant positive connection between $M C$ concentration and $m c y E$ genes was found in Lake Peipsi, this study revealed that the dynamics of the MC quota per $m c y E$ gene and $M C$ concentration in the water was not concurrent (Figure 5). A lower microcystin quota per $m c y E$ gene occurred together with higher MC concentrations and vice versa. A significant negative correlation was also found between MC quota per $m c y E$ gene and the abundance of $m c y E$ genes. Therefore, we found that our results only partly supported our second hypothesis, which states that mcyE copy number could be used as a direct predictor of MC concentration in the lake. Although there appears to be a correlation between $m c y E$ gene numbers and microcystins, the variation in the cellular quota of microcystins may lead to under- or overestimation of the risk when merely based on $m c y E$ gene numbers. This means that, in the situation where low numbers of $m c y E$ genes correspond to a higher toxin quota per $m c y E$ gene, the public health concern is higher, as it is subjected to a higher toxicity potential. If a low amount of toxic cells in the water can produce very high toxin concentrations in the water after cell lysis, then larger gene copies could rapidly reach extreme $\mathrm{MC}$ concentrations. This is in accordance with earlier observations where the MC quota is calculated with biomass or chl-a $[73,80]$. To estimate the risk for the water consumers, it is important to understand the reason behind the higher toxin quota when the biomass and $m c y E$ gene copy numbers are rather low [80]. In response to environmental conditions, the toxin quota per cell in toxin-producing species can vary largely [13]. In our study, the MC quota per $m c y E$ gene was related positively to water temperature and $\mathrm{pH}$, and negatively to the concentration of nitrate, but no significant correlation was found with total nitrogen or total phosphorus. This finding broadly supports the work 
of other studies in this area that link the dynamics of toxin quota per biomass with water temperature. A similar conclusion was also reported by Wood and others [81] in a shallow eutrophic lake in New Zealand, where MC quotas per biomass responded positively to surface water temperature. In another large-scale study, where 137 European lakes were analysed, the authors also report no direct impact of TP and TN on the toxin quota per chl-a, but found that water temperature is an important control factor [73]. Several other studies have shown the importance of water temperature as the regulatory factor of cyanobacterial biomass $[23,31,82,83]$ even on the global scale [84]. While nutrients play an important role through supporting the cyanobacterial community and biomass, the temperature seems to be to discriminative when other conditions are rather equal. These results demonstrate that, as global temperatures are expected to increase [85], in addition to an increase in the distribution, intensity, and duration of cyanobacterial blooms [23], the toxin concentration per cell will get higher. However, further in situ research is required to refine our understanding of the complex interaction between toxins, toxin quota per toxin gene and nutrients, as the findings about the effect of $\mathrm{NO}_{3}{ }^{-}$on the toxin quota in general still seem contradictory. Our study suggests a negative correlation between nitrates and toxin quota per $m c y E$ gene; one explanation for this inverse relationship can be the uptake of $\mathrm{NO}_{3}{ }^{-}$by toxin-producing cyanobacteria. The study by Horst and others [80] demonstrates a positive relationship between these variables and [81] did not detect any significant relationships between toxin quota and environmental parameters (including nitrates) other than the water temperature. However, as the role of nutrients is more complex, the absence of the significant relationship with nutrient-related parameters does not mean that the distribution and concentration of toxins are not influenced by nutrients. In addition, the mentioned studies used toxin quota calculated per biomass of cyanobacteria. We assume that, in general, the biomass of cyanobacteria or the concentration of chl-a are less reliable predictors of toxin concentration and the predictive power can be increased by measuring the absolute abundance of toxin production genes. Expanding this knowledge in further in situ studies would substantially contribute to appropriate lake management and risk assessment of the toxic blooms.

To conclude, we demonstrated that, even though the number of $m c y E$ gene copies increased together with toxin concentration, the variation in the cellular quota of microcystins may lead to underor overestimation of the risk when merely based on $m c y E$ gene copy numbers, and therefore $m c y E$ copy number should not be used as a single measure to predict MC concentration in Lake Peipsi. Additionally, we showed that specific toxin variants were directly related to certain cyanobacterial genera. P. agardhii was significantly related with only [D-Asp3]MC-RR and other MC variants formed a close group with $M$. wesenbergii, $M$. aeruginosa in $D$. flos-aquae. Further, nitrate was the only nutrient-related variable connected to MC quota per $m c y E$ gene. A strong positive correlation between water temperature and MC quota per $m c y E$ gene suggests that the warming trends might lead to more harmful cyanobacterial blooms in temperate shallow lakes.

\section{Materials and Methods}

\subsection{Study Site and Field Surveys}

During the growing season (May-Oct), water samples from the Estonian part of Lake Peipsi s.s. and Lämmijärv were collected biweekly in 2011 and monthly in 2012. In addition, samples from the whole lake were collected from 15 sampling stations in August during the Estonian-Russian joint sampling campaigns from the period 2010-2012. The coordinates of the studied sampling points are shown in Table S2. One hundred and forty-one depth-integrated water samples (depth range: surface to $0.5 \mathrm{~m}$ to the sediment) from 6-15 locations (Figure 1) were analysed.

Depth-integrated water was collected using a two-liter Van Dorn sampler at one-meter intervals and mixed in the collection bucket on the board of the research vessel. Integrated samples throughout the whole water column were collected due to the presence of buoyant cyanobacterial species. Subsamples for phytoplankton community composition analysis, molecular analyses of $m c y E$ gene abundance, and toxin analysis were collected onboard. Subsamples were stored in an onboard refrigerator and 
transported to the laboratory in the coolers for further processing. For DNA extraction, 100-2000 mL (depending on sampling point and time) of the depth-integrated water was filtered at a low vacuum (max. 0.2 bar) through $5 \mu \mathrm{m}$ pore size Whatman Cyclopore Polycarbonate filters. For toxin analyses, 150-1200 mL of the water was filtered through Binder-Free Glass Microfiber Grade GF/C (pore size $1.2 \mu \mathrm{m}, \mathrm{GE}$ Healthcare, UK) filter. Until further analysis, filters were stored at $-80^{\circ} \mathrm{C}$.

Water chemistry analyses were performed as a part of the state monitoring programme by Estonian Environmental Research Centre following international and Estonian quality standards (ISO and EVS-EN ISO).

\subsection{Microscopic Analysis}

Samples for phytoplankton community analyses $(n=141)$ were preserved with Lugol's (acidified iodine) solution and processed using the Utermöhl [33] method. Phytoplankton biomass was calculated from counts of cells using a Nikon Eclipse Ti-S inverted microscope at $\times 200$ and $\times 400$ magnification. Species were identified using classifications described in [86-88]. An aliquot of $3 \mathrm{~mL}$ was settled overnight. Biovolume of algal cells, colonies and/or filaments were calculated using assigned geometric shapes dimensions and converted to biomass assuming the specific density of $1 \mathrm{~g} / \mathrm{cm}^{3}$ in accordance with [89].

\subsection{Detection of Microcystins (MCs)}

MCs were identified from 69 environmental samples by LC-MS according to their microcystin characteristic protonated molecular ions $[\mathrm{M}-\mathrm{H}]^{-}$. The extracts were analysed (injection volume $5 \mu \mathrm{L}$ ) with an Agilent 1100 Series LC/MSD Trap System high-performance liquid chromatography (Agilent Technologies, PaloAlto, CA, USA.), which has an XCT Plus model ion trap as a mass detector. The ionization method used was electrospray ionization (ESI) in both positive and negative mode. The column used was Phenomenex Luna C8 (2) (150 by $2.0 \mathrm{~mm}, 5 \mu \mathrm{m}$ ) (Phenomenex, Torrance, CA, USA). Gradient was done with $0.1 \%$ formic acid in water (A) and $0.1 \%$ formic acid in 2-propanol (B) The gradient timetable was $20 \%$ B to $70 \%$ B over $37 \mathrm{~min}$, after which the washing of the column was performed for in 100\% B for $10 \mathrm{~min}$ and equilibrated in initial conditions for $12 \mathrm{~min}$. The flow rate was $0.15 \mathrm{~mL} / \mathrm{min}$ and the column temperature $40{ }^{\circ} \mathrm{C}$. In ion source nebulizer gas (N2), pressure was 35 psi, desolvation gas flow rate 8 litres/min, and the desolvation temperature was $350{ }^{\circ} \mathrm{C}$. The capillary voltage was set to $5000 \mathrm{~V}$, the capillary exit offset was $300 \mathrm{~V}$, the skimmer potential was $66 \mathrm{~V}$, and the trap drive value was 73. Spectra were recorded 700-1500 m/z. The total microcystin concentration of the strain was approximated with a microcystin-LR standard (a gift from Z. Grzonka, Faculty of Chemistry, University of Gdansk, Poland) and microcystin-RR (Alexis, Farmingdale, NY, USA.) To avoid the underestimation of smaller concentration in environmental samples, standard curves were constructed with only the six most diluted standards. The identification of MCs was based on fragmentation patterns of the ions in MS2, ion masses and their retention times.

\subsection{Cultivation of the Strains Used as External Standards}

Microcystin-producing strains Microcystis sp. 205, Dolichospermum sp. 315 and Planktothrix sp. 49 were grown in HAMBI/UHCC Culture Collection, University of Helsinki in a Z8 medium under the continuous light at $20 \pm 2$. These strains were used in the preparation of standard curves for qPCR.

\subsection{DNA Extraction}

For DNA extraction, $40 \mathrm{~mL}$ of standard cultures were concentrated by centrifugation (5 min at

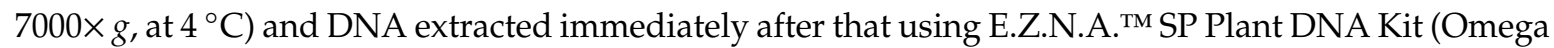
Bio-Tek, Norcross, GA, USA) according to the manufacturer's instructions. In addition to the protocol, the mechanical disruption of the cells with acid-washed glass beads (710-1180 $\mu$; Sigma-Aldrich Co, St. Louis, MO, USA) and FastPrep®FP 120 bead-beater (MP Biomedicals, LLC, Irvine, CA, USA) was used. DNA from environmental samples was extracted using the DNeasy PowerWater Kit (Qiagen 
Inc., Germantown, MD, USA) according to the manufacturer's instructions. The quality and quantity of extracted DNA were controlled with NanoDrop 2000 UV-Vis spectrophotometer (Thermo Fisher Scientific Inc., Waltham, MA, USA).

\subsection{Detection and Quantification of mcyE Genes in Environmental Samples}

To exclude false-negative outcome caused by the possible presence of PCR inhibitors in environmental samples, cyanobacterium-specific 16S rRNA PCR [90] was performed. PCR conditions are shown in Table A2. In order to identify the dominant potential microcystin-producing genera in environmental samples, genus-specific qPCRs were carried out. In order to detect Planktothrix mcyE genes in water samples, a new Planktothrix-specific primer pair and hydrolysis probe was designed (Table S3). PCR conditions were optimized, and specificity (Table S4) and sensitivity (Figure S2) experiments were performed as described before in [76].

The external standards of MC-producing strains were used to quantify $m c y E$ gene copy numbers. Standard dilutions of genomic DNA of the standards were prepared as described before [91]. To quantify Microsystis mcyE gene copies from lake samples, the standard dilution contained $10^{6}, 10^{5}, 10^{4}, 10^{3}$, $10^{2}, 10^{1}$ copies of mcyE genes. To determine $m c y E$ gene copies from Dolichospermum and Planktothrix, standard dilutions contained $10^{5}, 2 \times 10^{4}, 4 \times 10^{3}, 8 \times 10^{2}, 1.6 \times 10^{2}, 3.2 \times 10^{1}$ and $10^{1}$ copies of mcyE genes.

The reaction mixture in total volume of $20 \mu \mathrm{L}$ included $5 \mu \mathrm{L}$ of standard or environmental DNA, $1 \times$ HOT FIREPol $@$ Probe qPCR Mix Plus, with ROX (Solis BioDyne, Tartu, Estonia), $300 \mathrm{nM}$ of both primers (Metabion international AG, Planegg, Germany) (Table A2) and $200 \mathrm{nM}$ of TaqMan®probe (with an exception for Planktothrix, where $300 \mathrm{nM}$ of TaqMan®probe was used). Environmental DNA samples were diluted 1:50 (to detect Microcystis) or 1:10 (to detect Dolichospermum and Planktothrix), MQ water was used as a negative control, and all the reactions were performed in three replicates. Amplifications were performed on an ABI 7500 Fast Real-Time PCR system (Thermo Fisher Scientific Inc, Waltham, MA, USA) using the following protocol: $95^{\circ} \mathrm{C}$ for $12 \mathrm{~min}$ for initial denaturation, 40 cycles of $95^{\circ} \mathrm{C}$ for $15 \mathrm{~s}$ and $62{ }^{\circ} \mathrm{C}$ (Microcystis mcyE and Dolichospermum mcyE) or $60{ }^{\circ} \mathrm{C}$ (Planktothrix $m c y E$ ) for $1 \mathrm{~min}$. Results were analysed using 7500 Software version 2.0.5.

The microcystin toxin quota was calculated by dividing particulate microcystin concentration $(\mu \mathrm{g} / \mathrm{mL})$ by $m c y E$ gene copies $/ \mathrm{mL}$.

\subsection{Statistical Analyses}

All statistical analyses were performed with the R package and its extensions [92] and STATISTICA 13 (TIBCO Software Inc., PaloAlto, CA, USA). To analyse cyanobacterial community composition and to compare the communities from different lake basins (sampling stations), we used a between-groups principal component analysis (bgPCA, R ade4) on the abundance data. The statistical significance $(p<0.05)$ of bgPCA was tested by a Monte Carlo permutation test (1000 replicates; [93].

Wilcoxon pairwise test was used to analyse the differences between gene abundance of Microcystis mcyE, Dolichospermum mcyE and Planktothrix mcyE. Pearson correlation $\left(\mathrm{r}_{\mathrm{p}}\right)$ analysis on log-transformed data was used to test associations between Microcystis, Dolichospermum and Planktothrix specific mcyE gene abundance and total microcystin concentrations in the samples. In case the data lacked normal distribution even after logarithmic transformation, the Spearman rank-order correlation $\left(\mathrm{r}_{\mathrm{s}}\right)$ coefficient was used.

Mantel test was performed to describe the relationship between matrices of microscopy counting data including cyanobacterial species potentially able to produce toxins and MC concentration. For this, the species list of cyanobacteria was compiled according to the historical records (provided by R. Laugaste) of phytoplankton species in Lake Peipsi. The potential ability to produce toxins was added from the list of toxin-producing cyanobacteria published by [1,25,32].

Multivariate comparisons of various $m c y E$ gene abundances and presence/absence of $M C$ variants were analysed using the subset of existing observations $(n=69)$ in PCA and linear fitting of independent 
variables (envfit function in $\mathrm{R}$ vegan). A similar analysis was used to determine the relationship between the abundance of cyanobacteria and environmental physico-chemical variables. The significance $(p<0.05)$ of these linear fittings was obtained by permutation test (1000 replicates).

The microcystin quota was calculated by dividing MC concentration by mycE gene variants abundance (copy number/mL). Thereafter, the association between microcystin quota per $m c y E$ gene and MC variant presence/absence was analysed by logistic linear modelling (glm function with binomial family in $\mathrm{R}$ base).

Supplementary Materials: The following are available online at http://www.mdpi.com/2072-6651/12/4/211/s1, Table S1: Species composition of cyanobacteria in Lake Peipsi, Table S2: Coordinates of the sampling points, Table S3: Sequences of the primers and hydrolysis probe designed to detect and quantify Planktothrix mcyE genes in environmental samples by qPCR assay, Table S4: Average threshold-cycle values (SD) of three replicate reactions obtained with cyanobacterial strains used to test the specificity of the genus-specific Planktothrix mcyE gene qPCR assay,. Figure S1: correlation between MC concentration and the sum of Microcystis, Dolichospermum and Planktothrix mcyE gene copy numbers. Figure S2: Average threshold cycles and standard deviations of triplicate Planktothrix mcyE targeted by qPCR assays. Assays were performed either with $10^{4}$ or $10^{2}$ copies of target $m c y E$ gene and $0,10^{3}, 10^{4}, 10^{5}$, or $10^{6}$ copies of competing $m c y E$ genes of two other microcystin-producing strains. Strain abbreviations: P126/8 - Planktothrix agardhii 126/8; A90 - Dolichospermum sp. 90 and M7806 - Microcystis aeruginosa. PCC 7806.

Author Contributions: Conceptualization of this study was made by K.P., A.R.-Y. and K.S.; sampling design by K.P. and R.L.; data collection was performed by K.P. and O.T.; data analyses were performed by K.P.; M.T. and V.K.; K.P. prepared the original draft, supervised by V.K.; review and editing was performed by K.P., M.T., E.M., A.R.-Y., R.L., O.T., K.S. and V.K. All authors have read and agreed to the published version of the manuscript.

Funding: This research was supported by Estonian Research Council grant PUT 1389, PUT PRG709, PUTJD913, base financed projects P170024PKKH and P180023PKKH of Estonian University of Life Sciences, Institute of Technology, University of Tartu basic funding grant, national scholarship program Dora, which is funded and managed by Archimedes Foundation in collaboration with the Estonian Ministry of Education and Research.

Acknowledgments: The authors acknowledge CYANOCOST-COST ES 1105 “Cyanobacterial blooms and toxins in water resources: Occurrence impacts and management" for networking, sharing of knowledge and funding personal training of K.P. We thank Matti Wahlsten for LC-MS/MS analysis and Lyudmila Saari for cyanobacterial culture maintenance. We are grateful to David Schryer and Martin Leiger for the valuable language revision on the manuscript.

Conflicts of Interest: The authors declare no conflict of interest.

\section{Appendix A}

Table A1. Long term key characteristics of different basins of Lake Peipsi.

\begin{tabular}{cccc}
\hline Characteristic & Peipsi s.s. ${ }^{*}$ & Lämmijärv & Pihkva ** $^{*}$ \\
\hline Secchi depth, $\mathrm{m}$ & $1.8(1 ; 2.8)$ & $1(0.6 ; 1.8)$ & $0.61(0.4 ; 0.8)$ \\
$\mathrm{TP}, \mathrm{mg} / \mathrm{m}^{3}$ & $41(21 ; 80)$ & $69(40 ; 130)$ & $133(57 ; 201)$ \\
$\mathrm{SRP}, \mathrm{mg} / \mathrm{m}^{3}$ & $8.6(2 ; 25)$ & $11.8(4 ; 30)$ & $25.6(30 ; 110)$ \\
$\mathrm{TN}, \mathrm{mg} / \mathrm{m}^{3}$ & $672(430 ; 1500)$ & $868(600 ; 1400)$ & $1190(948 ; 1525)$ \\
$\mathrm{NO}_{3}-, \mathrm{mg} / \mathrm{m}^{3}$ & $46(10 ; 240)$ & $42(10 ; 300)$ & $58(30 ; 110)$ \\
$\mathrm{NO}_{2}-, \mathrm{mg} / \mathrm{m}^{3}$ & $1.7(1 ; 6)$ & $1.8(1 ; 4)$ & $2.4(1.9 ; 4.4)$ \\
$\mathrm{NH}_{4}+, \mathrm{mg} / \mathrm{m}^{3}$ & $1.7(1 ; 6)$ & $28(10 ; 99)$ & $25(15 ; 33)$ \\
$\mathrm{Chl} \mathrm{a,} \mathrm{mg/m}$ & $15.8(5.6 ; 40.5)$ & $30(9.6 ; 70.5)$ & $68(33.7 ; 123.5)$ \\
OECD classification & Eutrophic & Eutrophic/hypertrophic & Hypertrophic \\
\hline
\end{tabular}

* the geometrical mean values for growing season (1992-2012). ${ }^{* *}$ the geometrical mean values for August (2003-2012) $95 \%$ quantiles in brackets. 
Table A2. Primers and probes used in the study.

\begin{tabular}{|c|c|c|c|}
\hline Target Gene & Primer & Primer Reference & PCR Program \\
\hline $\begin{array}{c}\text { Cyanobacterial 16S } \\
\text { rRNA }\end{array}$ & $\begin{array}{l}\text { CYA359F } \\
\text { CYA781R }\end{array}$ & [90] & $\begin{array}{c}95^{\circ} \mathrm{C} 5 \mathrm{~min} ; 35 \text { cycles: } 95 \\
{ }^{\circ} \mathrm{C} 60 \mathrm{~s} ; 60^{\circ} \mathrm{C} 60 \mathrm{~s} ; 72{ }^{\circ} \mathrm{C} \\
60 \mathrm{~s} \text { and } 72{ }^{\circ} \mathrm{C} 10 \mathrm{~min}\end{array}$ \\
\hline Microcystis mcyE & $\begin{array}{l}127 \mathrm{~F} \\
247 \mathrm{R} \\
186 \mathrm{P}\end{array}$ & [76] & $\begin{array}{l}95^{\circ} \mathrm{C} 15 \mathrm{~min} ; 40 \text { cycles: } \\
95^{\circ} \mathrm{C} 15 \mathrm{~s} ; 62^{\circ} \mathrm{C} 60 \mathrm{~s}\end{array}$ \\
\hline Dolichospermum mсyE & $\begin{array}{l}611 \mathrm{~F} \\
737 \mathrm{R} \\
672 \mathrm{P}\end{array}$ & [76] & $\begin{array}{l}95^{\circ} \mathrm{C} 15 \mathrm{~min} ; 40 \text { cycles: } \\
95^{\circ} \mathrm{C} 15 \mathrm{~s} ; 62^{\circ} \mathrm{C} 60 \mathrm{~s} ;\end{array}$ \\
\hline Planktothrix mcyE & $\begin{array}{l}664 \mathrm{~F} \\
744 \mathrm{R} \\
670 \mathrm{P}\end{array}$ & $\begin{array}{l}\text { Current study, } \\
\text { Table S3 }\end{array}$ & $\begin{array}{l}95^{\circ} \mathrm{C} 15 \mathrm{~min} ; 40 \text { cycles: } \\
95^{\circ} \mathrm{C} 15 \mathrm{~s} ; 60^{\circ} \mathrm{C} 60 \mathrm{~s} ;\end{array}$ \\
\hline
\end{tabular}

\section{References}

1. Chorus, I.; Bartram, J. Introduction. In Toxic Cyanobacteria in Water: A Guide to Their Public Health Consequences, Monitoring and Management; E \& FN Spon: London, UK, 1999; Volume 1, pp. 14-24.

2. Jeppesen, E.; Meerhoff, M.; Davidson, T.A.; Trolle, D.; SondergaarD, M.; Lauridsen, T.L.; Beklioglu, M.; Brucet Balmaña, S.; Volta, P.; González-Bergonzoni, I.; et al. Climate change impacts on lakes: An integrated ecological perspective based on a multi-faceted approach, with special focus on shallow lakes. J. Limnol. 2014, 73, 88-111. [CrossRef]

3. Reynolds, C.S. The Ecology of Phytoplankton; Cambridge University Press: Cambridge, UK, 2006.

4. Paerl, H.W.; Paul, V.J. Climate change: Links to global expansion of harmful cyanobacteria. Water Res. 2012, 46, 1349-1363. [CrossRef] [PubMed]

5. Paerl, H.W.; Otten, T.G. Harmful cyanobacterial blooms: Causes, consequences, and controls. Microb. Ecol. 2013, 65, 995-1010. [CrossRef] [PubMed]

6. Jöhnk, K.D.; Huisman, J.; Sharples, J.; Sommeijer, B.; Visser, P.M.; Stroom, J.M. Summer heatwaves promote blooms of harmful cyanobacteria. Glob. Chang. Biol. 2008, 14, 495-512. [CrossRef]

7. Huber, V.; Wagner, C.; Gerten, D.; Adrian, R. To bloom or not to bloom: Contrasting responses of cyanobacteria to recent heat waves explained by critical thresholds of abiotic drivers. Oecologia 2012, 169, 245-256. [CrossRef]

8. Paerl, H.W.; Hall, N.S.; Peierls, B.L.; Rossignol, K.L. Evolving Paradigms and Challenges in Estuarine and Coastal Eutrophication Dynamics in a Culturally and Climatically Stressed World. Estuaries Coasts 2014, 37, 243-258. [CrossRef]

9. Woznicki, S.A.; Nejadhashemi, A.P.; Tang, Y.; Wang, L. Large-scale climate change vulnerability assessment of stream health. Ecol. Indic. 2016, 69, 578-594. [CrossRef]

10. Le Moal, M.; Gascuel-Odoux, C.; Ménesguen, A.; Souchon, Y.; Étrillard, C.; Levain, A.; Moatar, F.; Pannard, A.; Souchu, P.; Lefebvre, A.; et al. Eutrophication: A new wine in an old bottle? Sci. Total. Environ. 2019, 651, 1-11. [CrossRef]

11. Huisman, J.; Codd, G.A.; Paerl, H.W.; Ibelings, B.W.; Verspagen, J.M.H.; Visser, P.M. Cyanobacterial blooms. Nat. Rev. Microbiol. 2018, 16, 471-483. [CrossRef]

12. Kosten, S.; Huszar, V.L.M.; Bécares, E.; Costa, L.S.; Donk, E.; Hansson, L.-A.; Jeppesen, E.; Kruk, C.; Lacerot, G.; Mazzeo, N.; et al. Warmer climates boost cyanobacterial dominance in shallow lakes. Glob. Chang. Biol. 2012, 18, 118-126. [CrossRef]

13. Sivonen, K.; Jones, G. Cyanobacterial toxins. In Toxic Cyanobacteria in Water: A Guide to their Public Health Consequences, Monitoring and Management; E \& FN Spon: London, UK, 1999; Volume 1, pp. 43-112.

14. Hudnell, H.K. The state of U.S. freshwater harmful algal blooms assessments, policy and legislation. Toxicon 2010, 55, 1024-1034. [CrossRef]

15. Sieroslawska, A.; Rymuszka, A.; Velisek, J.; Pawlik-Skowrońska, B.; Svobodova, Z.; Skowroński, T. Effects of microcystin-containing cyanobacterial extract on hematological and biochemical parameters of common carp (Cyprinus carpio L.). Fish Physiol. Biochem. 2012, 38, 1159-1167. [CrossRef]

16. Metcalf, J.S.; Codd, G.A. Cyanobacterial Toxins (Cyanotoxins) in Water; Foundation for Water Research: Marlow, UK, 2014. 
17. Dodds, W.K.; Bouska, W.W.; Eitzmann, J.L.; Pilger, T.J.; Pitts, K.L.; Riley, A.J.; Schloesser, J.T.; Thornbrugh, D.J. Eutrophication of U.S. freshwaters: Analysis of potential economic damages. Environ. Sci. Technol. 2009, 43, 12-19. [CrossRef]

18. Steffensen, D.A. Economic cost of cyanobacterial blooms. In Cyanobacterial Harmful Algal Blooms: State of the Science and Research Needs; Hudnell, H.K., Ed.; Springer: New York, NY, USA, 2008; pp. 855-865, ISBN 978-0-387-75865-7.

19. Carmichael, W.W. Health Effects of Toxin-Producing Cyanobacteria: “The CyanoHABs". Hum. Ecol. Risk Assess. Int. J. 2001, 7, 1393-1407. [CrossRef]

20. Paerl, H.W. Mitigating harmful cyanobacterial blooms in a human- and climatically-impacted world. Life 2014, 4, 988-1012. [CrossRef] [PubMed]

21. Freitas, E.C.; Pinheiro, C.; Rocha, O.; Loureiro, S. Can mixtures of cyanotoxins represent a risk to the zooplankton? The case study of Daphnia magna Straus exposed to hepatotoxic and neurotoxic cyanobacterial extracts. Harmful Algae 2014, 31, 143-152. [CrossRef] [PubMed]

22. Merel, S.; Walker, D.; Chicana, R.; Snyder, S.; Baurès, E.; Thomas, O. State of knowledge and concerns on cyanobacterial blooms and cyanotoxins. Environ. Int. 2013, 59, 303-327. [CrossRef] [PubMed]

23. Paerl, H.W.; Huisman, J. Climate. Blooms like it hot. Science 2008, 320, 57-58. [CrossRef]

24. Søndergaard, M.; Jensen, J.P.; Jeppesen, E. Role of sediment and internal loading of phosphorus in shallow lakes. Hydrobiologia 2003, 506, 135-145. [CrossRef]

25. Salmaso, N.; Bernard, C.; Humbert, J.-F.C.; Akçaalan, R.; Albay, M.; Ballot, A.; Catherine, A.; Fastner, J.; Häggqvist, K.; Horecká, M.; et al. Basic guide to detection and monitoring of potentially toxic cyanobacteria. In Handbook of Cyanobacterial Monitoring and Cyanotoxin Analysis; John Wiley \& Sons: Chichester, UK, 2017; Volume 6, pp. 46-69.

26. Downing, J.A.; Watson, S.B.; McCauley, E. Predicting Cyanobacteria dominance in lakes. Can. J. Fish Aquat. Sci. 2001, 58, 1905-1908. [CrossRef]

27. Cózar, A.; Gálvez, J.A.; Hull, V.; García, C.M.; Loiselle, S.A. Sediment resuspension by wind in a shallow lake of Esteros del Ibera (Argentina): A model based on turbidimetry. Ecol. Model. 2005, 186, 63-76. [CrossRef]

28. Bormans, M.; Maršálek, B.; Jančula, D. Controlling internal phosphorus loading in lakes by physical methods to reduce cyanobacterial blooms: A review. Aquat. Ecol. 2016, 50, 407-422. [CrossRef]

29. Paerl, H.W.; Xu, H.; McCarthy, M.J.; Zhu, G.; Qin, B.; Li, Y.; Gardner, W.S. Controlling harmful cyanobacterial blooms in a hyper-eutrophic lake (Lake Taihu, China): The need for a dual nutrient (N \& P) management strategy. Water Res. 2011, 45, 1973-1983. [PubMed]

30. Molot, L.A.; Watson, S.B.; Creed, I.F.; Trick, C.G.; Mccabe, S.K.; Verschoor, M.J.; Sorichetti, R.J.; Powe, C.; Venkiteswaran, J.J.; Schiff, S.L. A novel model for cyanobacteria bloom formation: The critical role of anoxia and ferrous iron. Freshw. Biol. 2014, 59, 1323-1340. [CrossRef]

31. Paerl, H.W.; Gardner, W.S.; Havens, K.E.; Joyner, A.R.; McCarthy, M.J.; Newell, S.E.; Qin, B.; Scott, J.T. Mitigating cyanobacterial harmful algal blooms in aquatic ecosystems impacted by climate change and anthropogenic nutrients. Harmful Algae 2016, 54, 213-222. [CrossRef]

32. Codd, G.A.; Meriluoto, J.; Metcalf, J.S. Introduction: Cyanobacteria, Cyanotoxins, Their Human Impact, and Risk Management. In Handbook of Cyanobacterial Monitoring and Cyanotoxin Analysis; Meriluoto, J., Spoof, L., Codd, G.A., Eds.; John Wiley \& Sons, Ltd: Chichester, UK, 2016; Volume 51, pp. 1-8.

33. Utermöhl, H. Zur vervollkommnung der quantitativen phytoplankton-methodik: Mit 1 Tabelle und 15 abbildungen im Text und auf 1 Tafel. Mitt. Int. Ver. Angew. Limnol. 1958, 9, 1-38. [CrossRef]

34. Pacheco, A.B.F.; Guedes, I.A.; Azevedo, S.M.F.O. Is qPCR a reliable indicator of cyanotoxin risk in freshwater? Toxins 2016, 8, 172. [CrossRef]

35. Tamm, M.; Ligi, M.; Panksep, K.; Teeveer, K.; Freiberg, R.; Laas, P.; Paavel, B.; Kutser, T.; Reinart, A.; Tõnno, I.; et al. Boosting the monitoring of phytoplankton in optically complex coastal waters by combining pigment-based chemotaxonomy and in situ radiometry. Ecol. Indic. 2019, 97, 329-340. [CrossRef]

36. Hisbergues, M.; Christiansen, G.; Rouhiainen, L.; Sivonen, K.; Börner, T. PCR-based identification of microcystin-producing genotypes of different cyanobacterial genera. Arch. Microbiol. 2003, 180, 402-410. [CrossRef] 
37. Rantala, A.; Rajaniemi-Wacklin, P.; Lyra, C.; Lepistö, L.; Rintala, J.; Mankiewicz-Boczek, J.; Sivonen, K. Detection of microcystin-producing cyanobacteria in Finnish lakes with genus-specific microcystin synthetase gene E (mcyE) PCR and associations with environmental factors. Appl. Environ. Microbiol 2006, 72, 6101-6110. [CrossRef]

38. Baxa, D.V.; Kurobe, T.; Ger, K.A.; Lehman, P.W.; Teh, S.J. Estimating the abundance of toxic Microcystis in the San Francisco Estuary using quantitative real-time PCR. Harmful Algae 2010, 9, 342-349. [CrossRef]

39. Jaani, A. The location, size and general characterization of Lake Peipsi and its catchment area. In Lake Peipsi: Meteorology, Hydrology, Hydrochemistry; Nõges, T., Ed.; Sulemees Publishers: Tartu, Estonia, 2001; pp. 10-17.

40. Kangur, K.; Möls, T. Changes in spatial distribution of phosphorus and nitrogen in the large north-temperate lowland Lake Peipsi (Estonia/Russia). Hydrobiologia 2008, 599, 31-39. [CrossRef]

41. Noges, T.; Tuvikene, L.; Noges, P. Contemporary trends of temperature, nutrient loading, and water quality in large Lakes Peipsi and Vortsjärv, Estonia. Aquat Ecosyst Health Manag 2010, 13, 143-153. [CrossRef]

42. Loigu, E.; Leisk, Ü.; Iital, A.; Pachel, K. Pollution load and water quality of the Lake Peipsi basin. In Peipsi; Eesti Loodusfoto: Tartu, Estonia, 2008; Volume 2008, pp. 179-199.

43. Hydrobiological Monitoring of Lake Peipsi. Available online: https://kese.envir.ee/kese/listPublicReport. action (accessed on 15 January 2020).

44. Laugaste, R.; Panksep, K.; Haldna, M. Dominant cyanobacterial genera in Lake Peipsi (Estonia/Russia): Effect of weather and nutrients in summer months. Est. J. Ecol. 2013, 62, 229-243. [CrossRef]

45. Laugaste, R.; Nõges, T.; Tõnno, I. Vetikad. In Peipsi; Eesti Loodusfoto: Tartu, Estonia, 2008; pp. $251-270$.

46. Laugaste, R.; Haberman, J.; Krause, T.; Salujõe, J. Significant changes in phyto-and zooplankton in L. Peipsi in recent years: What is the underlying reason. Proc. Est. Acad. Sci. Biol. Ecol. 2007, 56, 106-123.

47. Tammeorg, O.; Niemistö, J.; Möls, T.; Laugaste, R.; Panksep, K.; Kangur, K. Wind-induced sediment resuspension as a potential factor sustaining eutrophication in large and shallow Lake Peipsi. Aquat. Sci. 2013, 75, 559-570. [CrossRef]

48. Tammeorg, O.; Horppila, J.; Tammeorg, P.; Haldna, M.; Niemistö, J. Internal phosphorus loading across a cascade of three eutrophic basins: A synthesis of short- and long-term studies. Sci. Total. Environ. 2016, 572, 943-954. [CrossRef]

49. Tanner, R.; Kangur, K.; Spoof, L.; Meriluoto, J. Hepatotoxic cyanobacterial peptides in Estonian freshwater bodies and inshore marine water. Proc. Eston. Acad. Sci. Biol. Ecol. 2005, 54, 40-52.

50. Merel, S.; Villarín, M.C.; Chung, K.; Snyder, S. Spatial and thematic distribution of research on cyanotoxins. Toxicon 2013, 76, 118-131. [CrossRef]

51. Meriluoto, J.; Blaha, L.; Bojadzija, G.; Bormans, M.; Brient, L.; Codd, G.A.; Drobac, D.; Faassen, E.J.; Fastner, J.; Hiskia, A.; et al. Toxic cyanobacteria and cyanotoxins in European waters-recent progress achieved through the CYANOCOST Action and challenges for further research. Adv. Oceanogr. Limnol. 2017, 8, 161-178. [CrossRef]

52. Guedes, I.A.; Pacheco, A.B.F.; Vilar, M.C.P.; Mello, M.M.; Marinho, M.M.; Lurling, M.; Azevedo, S.M.F.O. Intraspecific variability in response to phosphorus depleted conditions in the cyanobacteria Microcystis aeruginosa and Raphidiopsis raciborskii. Harmful Algae 2019, 86, 96-105. [CrossRef] [PubMed]

53. Halstvedt, C.B.; Rohrlack, T.; Andersen, T.; Skulberg, O.; Edvardsen, B. Seasonal dynamics and depth distribution of Planktothrix spp. in Lake Steinsfjorden (Norway) related to environmental factors. J. Plankton Res. 2007, 29, 471-482. [CrossRef]

54. Oberhaus, L.; Briand, J.F.; Leboulanger, C.; Jacquet, S.; Humbert, J.F. Comparative effects of the quality and quantity of light and temperature on the growth of Planktothrix agardhii and P. rubescens. J. Phycol. 2007, 43, 1191-1199. [CrossRef]

55. Istvánovics, V.; Osztoics, A.; Honti, M. Dynamics and ecological significance of daily internal load of phosphorus in shallow Lake Balaton, Hungary. Freshw. Biol. 2004, 49, 232-252. [CrossRef]

56. Steinman, A.; Chu, X.; Ogdahl, M. Spatial and temporal variability of internal and external phosphorus loads in Mona Lake, Michigan. Aquat. Ecol. 2009, 43, 1-18. [CrossRef]

57. Nürnberg, G.K. Assessing internal phosphorus load-Problems to be solved. Lake Reserv. Manag. 2009, 25, 419-432. [CrossRef]

58. Nürnberg, G.K.; LaZerte, B.D. More than 20 years of estimated internal phosphorus loading in polymictic, eutrophic Lake Winnipeg, Manitoba. J. Gt. Lakes Res. 2016, 42, 18-27. [CrossRef] 
59. Tammeorg, O.; Horppila, J.; Möls, T.; Haldna, M.; Laugaste, R.; Niemistö, J. Studies of legacy internal phosphorus load in Lake Peipsi (Estonia/Russia). In Internal Phosphorus Loading in Lakes: Causes, Case Studies and Management; Steinman, A., Spears, B., Eds.; J. Ross Publishing: Plantation, FL, USA, 2019; pp. 187-209.

60. Hyenstrand, P.; Blomqvist, P.; Pettersson, A. Factors determining cyanobacterial success in aquatic systems: A literature review. Adv. Limnol. 1998, 51, 41-62.

61. Haldna, M.; Milius, A.; Laugaste, R.; Kangur, K. Nutrients and phytoplankton in Lake Peipsi during two periods that differed in water level and temperature. Hydrobiologia 2008, 599, 3-11. [CrossRef]

62. Tammeorg, O.; Möls, T.; Kangur, K. Weather conditions influencing phosphorus concentration in the growing period in the large shallow Lake Peipsi (Estonia/Russia). J. Limnol. 2014, 73, 27-35. [CrossRef]

63. Ye, W.; Liu, X.; Tan, J.; Li, D.; Yang, H. Diversity and dynamics of microcystin-Producing cyanobacteria in China's third largest lake, Lake Taihu. Harmful Algae 2009, 8, 637-644. [CrossRef]

64. Otten, T.G.; Xu, H.; Qin, B.; Zhu, G.; Paerl, H.W. Spatiotemporal patterns and ecophysiology of toxigenic microcystis blooms in Lake Taihu, China: Implications for water quality management. Environ. Sci. Technol. 2012, 46, 3480-3488. [CrossRef] [PubMed]

65. Yu, L.; Kong, F.; Zhang, M.; Yang, Z.; Shi, X.; Du, M. The dynamics of microcystis genotypes and microcystin production and associations with environmental factors during blooms in Lake Chaohu, China. Toxins 2014, 6, 3238-3257. [CrossRef]

66. Bartlett, S.L.; Brunner, S.L.; Klump, J.V.; Houghton, E.M.; Miller, T.R. Spatial analysis of toxic or otherwise bioactive cyanobacterial peptides in Green Bay, Lake Michigan. J. Gt. Lakes Res. 2018, 44, 924-933. [CrossRef]

67. Rinta-Kanto, J.M.; Ouellette, A.J.A.; Boyer, G.L.; Twiss, M.R.; Bridgeman, T.B.; Wilhelm, S.W. Quantification of toxic Microcystis spp. during the 2003 and 2004 blooms in western Lake Erie using quantitative real-time PCR. Environ. Sci. Technol. 2005, 39, 4198-4205. [CrossRef]

68. Rinta-Kanto, J.M.; Konopko, E.A.; DeBruyn, J.M.; Bourbonniere, R.A.; Boyer, G.L.; Wilhelm, S.W. Lake Erie Microcystis: Relationship between microcystin production, dynamics of genotypes and environmental. Harmful Algae 2009, 8, 665-673. [CrossRef]

69. Wood, S.A.; Maier, M.Y.; Puddick, J.; Pochon, X.; Zaiko, A.; Dietrich, D.R.; Hamilton, D.P. Trophic state and geographic gradients influence planktonic cyanobacterial diversity and distribution in New Zealand lakes. FEMS Microbiol. Ecol. 2017, 93, fiw234. [CrossRef]

70. Panksep, K.; Agasild, H.; Tõnno, I.; Nõges, T. Cyanobacteria and Cyanotoxins in a Diet of Zooplankton in Shallow Eutrophic Lakes. (Unpublished; manuscript in preparation).

71. Arnaud, C.; Bernard, C.; Spoof, L.; Bruno, M. Microcystins and Nodularins. In Handbook of Cyanobacterial Monitoring and Cyanotoxin Analysis; Meriluoto, J., Spoof, L., Codd, G.A., Eds.; John Wiley \& Sons, Ltd.: Chichester, UK, 2016; Volume 1, pp. 107-126.

72. Sivonen, K.; Namikoshi, M.; Luukkainen, R.; Färdig, M.; Rouhiainen, L.; Evans, W.R.; Carmichael, W.W.; Rinehart, K.L.; Niemelä, S.I. Variation of Cyanobacterial Hepatotoxins in Finland. In Detection Methods for Cynobacterial Toxins; Codd, G.A., Jefferies, T.M., Keevil, C.W., Potter, E., Eds.; Woodhead Publishing: Sawston, UK, 1994; pp. 152-154, ISBN 978-1-85573-802-7.

73. Mantzouki, E.; Lürling, M.; Fastner, J.; de Senerpont Domis, L.; Wilk-Woźniak, E.; Koreivienė, J.; Seelen, L.; Teurlincx, S.; Verstijnen, Y.; Krztoń, W.; et al. Temperature Effects Explain Continental Scale Distribution of Cyanobacterial Toxins. Toxins 2018, 10, 156. [CrossRef]

74. Mantzouki, E.; Ibelings, B.W. The Principle and Value of the European Multi Lake Survey. Limnol. Ocean. Bull. 2018, 27, 82-86. [CrossRef]

75. Panksep, K.; Mantzouki, E.; Lurling, M.; Fastner, J.; Visser, P.; Tammert, H.; Ibelings, B.W. A continental scale multilake survey of cyanobacteria, toxin synthetase genes and toxins during a heatwave summer. In Proceedings of the 19th International Conference on harmful Algae (ICHA 2018), Nantes, France, 21-26 October 2018; p. 176.

76. Sipari, H.; Rantala-Ylinen, A.; Jokela, J.; Oksanen, I.; Sivonen, K. Development of a chip assay and quantitative PCR for detecting microcystin synthetase E gene expression. Appl. Environ. Microbiol. 2010, 76, 3797-3805. [CrossRef] [PubMed]

77. Christiansen, G.; Molitor, C.; Philmus, B.; Kurmayer, R. Nontoxic strains of cyanobacteria are the result of major gene deletion events induced by a transposable element. Mol. Biol. Evol. 2008, 25, 1695-1704. [CrossRef] [PubMed] 
78. Rantala, A.; Fewer, D.P.; Hisbergues, M.; Rouhiainen, L.; Vaitomaa, J.; Börner, T.; Sivonen, K. Phylogenetic evidence for the early evolution of microcystin synthesis. Proc. Natl. Acad. Sci. USA 2004, 101, 568-573. [CrossRef] [PubMed]

79. Humbert, J.-F. Molecular tools for the detection of toxigenic Cyanobacteria in natural ecosystems. In Handbook of Cyanobacterial Monitoring and Cyanotoxin Analysis; Meriluoto, J., Spoof, L., Codd, G.A., Eds.; John Wiley \& Sons, Ltd.: Chichester, UK, 2016; Volume 37, pp. 280-283, ISBN 978-1-119-06876-1.

80. Horst, G.P.; Sarnelle, O.; White, J.D.; Hamilton, S.K.; Kaul, R.B.; Bressie, J.D. Nitrogen availability increases the toxin quota of a harmful cyanobacterium, Microcystis aeruginosa. Water Res. 2014, 54, 188-198. [CrossRef]

81. Wood, S.A.; Borges, H.; Puddick, J.; Biessy, L.; Atalah, J.; Hawes, I.; Dietrich, D.R.; Hamilton, D.P. Contrasting cyanobacterial communities and microcystin concentrations in summers with extreme weather events: Insights into potential effects of climate change. Hydrobiologia 2017, 785, 71-89. [CrossRef]

82. Visser, P.M.; Verspagen, J.M.H.; Sandrini, G.; Stal, L.J.; Matthijs, H.C.P.; Davis, T.W.; Paerl, H.W.; Huisman, J. How rising $\mathrm{CO}_{2}$ and global warming may stimulate harmful cyanobacterial blooms. Harmful Algae 2016, 54, 145-159. [CrossRef]

83. Cremona, F.; Tuvikene, L.; Haberman, J.; Nõges, P.; Nõges, T. Factors controlling the three-decade long rise in cyanobacteria biomass in a eutrophic shallow lake. Sci. Total. Environ. 2018, 621, 352-359. [CrossRef]

84. O'Neil, J.M.; Davis, T.W.; Burford, M.A.; Gobler, C.J. The rise of harmful cyanobacteria blooms: The potential roles of eutrophication and climate change. Harmful Algae 2012, 14, 313-334. [CrossRef]

85. Solomon, S.; Qin, D.; Manning, M.; Chen, Z.; Marquis, M.; Averyt, K.B.; Tignor, M.; Miller, H.L. The physical science basis. In Contribution of Working Group I to the Fourth Assessment Report of the Intergovernmental Panel on Climate Change; Cambridge University Press: Cambridge, UK; New York, NY, USA, 2007; Volume 996, p. 2007.

86. Komarek, J. Cyanoprokaryota 3. Teil: Heterocystous Genera. In Süsswasserflora von Mitteleuropa; Springer: Berlin/Heidelberg, Germany, 2013; Volume 19/3.

87. Komarek, J.; Anagnostidis, K. Cyanoprokaryota 1. Teil: Chroococcales. In Süsswasserflora von Mitteleuropa; Springer: Berlin/Heidelberg, Germany, 1999; Volume 19/1.

88. Komarek, J. Anagnostidis Cyanoprokaryota 2. Teil: Oscillatoriales. In Süsswasserflora von Mitteleuropa; Springer: Berlin/Heidelberg, Germany, 2005; Volume 19/31.

89. Edler, L. Recommendations on methods for marine biological studies in the Baltic Sea. Phytoplankton and chlorophyll. Publ. Balt. Mar. Biol. Bmb Swed. 1979, 9, 38.

90. Nubel, U.; Muyzer, G.; Garcia-pichel, F.; Muyzer, G. PCR primers to amplify 16S rRNA genes from cyanobacteria PCR Primers to Amplify 16S rRNA Genes from Cyanobacteria. Microbiology 1997, 63, 3327-3332.

91. Vaitomaa, J.; Rantala, A.; Halinen, K.; Rouhiainen, L.; Tallberg, P.; Mokelke, L.; Sivonen, K. Quantitative Real-Time PCR for Determination of Microcystin Synthetase E Copy Numbers for Microcystis and Anabaena in Lakes. Appl. Environ. Microbiol. 2003, 69, 7289-7297. [CrossRef] [PubMed]

92. R Core Team. R: A Language and Environment for Statistical Computing; R Foundation for Statistical Computing: Vienna, Austria, 2013.

93. Legendre, P.; Legendre, L. Developments in Environmental Modelling; Elsevier Science \& Technology Books: Amsterdam, The Netherlands, 1998; Volume 20, ISBN 978-0-08-052317-0.

(C) 2020 by the authors. Licensee MDPI, Basel, Switzerland. This article is an open access article distributed under the terms and conditions of the Creative Commons Attribution (CC BY) license (http://creativecommons.org/licenses/by/4.0/). 